NBER WORKING PAPER SERIES

\title{
GOING OFF PAROLE: HOW THE ELIMINATION OF DISCRETIONARY PRISON RELEASE AFFECTS THE SOCIAL COST OF CRIME
}

\author{
Ilyana Kuziemko \\ Working Paper 13380 \\ http://www.nber.org/papers/w13380 \\ NATIONAL BUREAU OF ECONOMIC RESEARCH \\ 1050 Massachusetts Avenue \\ Cambridge, MA 02138 \\ September 2007
}

I would like to thank David Cutler, Marvin Danielson, Edward Glaeser, Claudia Goldin, Caroline Hoxby, Larry Katz, Steve Levitt, Jeffrey Miron, Michael Norton and Shanna Rose for valuable comments on drafts, and seminar participants at Harvard, Princeton, Stanford, Columbia, Wharton, Yale SOM, Chicago, Chicago GSB, Michigan, Vanderbilt Law, Harvard Law, the Tinbergen Institute, University of Zurich, and LSE for their suggestions. I am deeply grateful to Dr. Tim Carr at the Georgia Department of Corrections for his generosity and patience. This paper has greatly benefited from conversations with Paul Bellatti and others at the Oregon Department of Corrections as well as a meeting with the state's parole board and tours of their correctional facilities. The views expressed herein are those of the author(s) and do not necessarily reflect the views of the National Bureau of Economic Research.

(C) 2007 by Ilyana Kuziemko. All rights reserved. Short sections of text, not to exceed two paragraphs, may be quoted without explicit permission provided that full credit, including (C) notice, is given to the source. 
Going Off Parole: How the Elimination of Discretionary Prison Release Affects the Social

Cost of Crime

Ilyana Kuziemko

NBER Working Paper No. 13380

September 2007

JEL No. H0,H43,H75

\begin{abstract}
In order to lengthen prison terms, many U.S. states have limited parole boards' traditional authority to grant early releases. I develop a framework in which the welfare effects of this reform depend on (1) the elasticity of future recidivism with respect to time in prison, (2) the accuracy of boards in conditioning release dates on recidivism risk, and (3) the extent to which such conditioning encourages inmates to reform. Using micro-data from Georgia and quasi-experimental variation arising from policy shocks and institutional features of its criminal justice system, I find that longer prison terms decrease recidivism, boards assign higher-risk inmates to longer terms, and inmates' investment in rehabilitative activities falls -- and their recidivism rises -- when boards' discretion is limited. Back-of-the-envelope calculations suggest that the benefits of parole (the ability to ration prison resources based on recidivism risk and the creation of incentives) outweigh the costs (lost incapacitation due to shorter prison terms).
\end{abstract}

Ilyana Kuziemko

Princeton University

361 Wallace Hall

Princeton, NJ 08544

and NBER

kuziemko@princeton.edu 


\section{Introduction}

The manner in which inmates are released from U.S. prisons has undergone sweeping change over the past 30 years. From the late $19^{\text {th }}$ century until recently, a judge typically would assign a convicted offender an indeterminate sentence (e.g., "ten years to life") and a parole board would decide when, within that range, the prisoner would be released. Until the 1980s, state and federal parole boards had the authority to release almost all felons; today less than onequarter of prison inmates are released via a parole-board decision (U.S. Bureau of Justice Statistics 2004). The movement from traditional parole-board discretion to fixed-sentences regimes where judges' decisions are binding could have potentially important effects on the incentives and efficiency of the U.S. criminal justice system, which currently incarcerates more than two million individuals and annually releases 600,000. However, the topic has received little attention from economists. ${ }^{1}$

Evaluating the social welfare impacts of parole reform is complicated by several competing effects. Policymakers' main goal in eliminating parole boards was to increase the length of time inmates spend in prison, as parole boards were viewed as overly lenient and longer terms may incapacitate dangerous criminals and deter future crime. ${ }^{2}$ Less attention was paid to the possible benefits of parole. For example, parole boards can use information about inmates' future recidivism revealed after sentencing to condition release dates on expected recidivism risk, thus more efficiently allocating prison resources relative to a system in which judges must set release dates at the time of trial. Moreover, abolishing parole could weaken

\footnotetext{
${ }^{1}$ Researchers in other fields have given more attention to parole reform; useful references include Western (2006), Petersilia (1999), and Abadinsky (2003).

2 Petersilia (1990) discusses how politicians and policymakers pushing for parole reform sought to increase the severity of punishment by limiting the discretion of parole boards, which were believed to be overly lenient.
} 
prisoners' incentives to invest in their own rehabilitation, as release is no longer tied to perceived risk, and thus may increase recidivism.

I develop a framework for evaluating the movement away from parole that encompasses these competing effects. The framework suggests that the difference in the social cost of crime under parole and fixed-sentences regimes depends on three empirical relationships: the effect of time served on recidivism (do longer prison terms reduce future criminal activity?); the accuracy with which parole boards condition release dates on expected recidivism risk (how well do parole boards perform their jobs?); and the effect of parole-based incentives on inmates' behavior while in prison and their recidivism once released (does the hope of parole make prisoners reform?). To estimate these relationships, I rely on a rich data set from the Georgia Department of Corrections (GDC) and on a number of institutional features and policy changes in the state that generate quasi-experimental variation in both time served and parole eligibility.

I first estimate the effect of time served on recidivism. Because inmates with higher recidivism risk generally serve longer terms, and because the risk may be only partially accounted for by controlling for observables, standard ordinary least squares estimates of the treatment effect of time served on recidivism are likely to be positively biased. The first identification strategy exploits an over-crowding crisis in 1981 that resulted in the release of 900 prisoners on a single day; conditional on the original sentence, the length of time served for this group was determined by the date the sentence began, which is plausibly exogenous. The second identification strategy uses variation in time served generated by cut-offs in parole-board guidelines in a regression-discontinuity design. Both estimations suggest that recidivism falls with time served. 
I then examine the accuracy of parole boards in forecasting inmates' expected recidivism risk. The estimation is complicated by mechanical endogeneity: in most cases, the parole board's recommendation is perfectly coincident with the length of time served by an inmate. I again exploit the 1981 mass release, a rare instance when the parole board's recommendation does not determine the date of release, as the overcrowding crisis essentially voided its decisions. I find that parole boards do indeed assign longer terms to those with higher initial risk, and do so in a manner that exactly offsets variation in inmates' initial risk, so that inmates are released when their expected recidivism falls below a certain threshold.

In an effort to confirm these results, I take advantage of the fact that parole boards can neither assign a recommendation beyond the original sentence nor release a prisoner before he serves about one-third of his sentence. I find that for inmates assigned between 40 and 90 percent of their sentence—-that is, when boards should be unconstrained—standard covariates contain substantially less explanatory power than for prisoners released near the lower and upper boundaries, suggesting that limiting parole board discretion leads to valuable information being left on the table.

Finally, to determine whether inmates respond to the incentives generated by parole boards, I analyze a 1998 policy reform in Georgia that effectively eliminated the possibility of parole for inmates convicted of certain crimes. Inmates in this group (who no longer had a chance at early release) were more likely to accumulate disciplinary infractions, less likely to complete courses such as GED preparation and vocational training, and more likely to return to prison after being released.

Overall, back-of-the-envelope calculations of the social cost of crime suggest that the benefits of parole regimes outweigh their costs. Empirically, parole appears linked to slightly 
shorter average prison terms and thus less incapacitation and less time for rehabilitation.

However, the ability to condition prison terms on recidivism risk and the creation of incentives for inmates to invest in rehabilitation while in prison appear to offset the loss due to shorter terms.

The paper is organized as follows. Section 1 provides a short history of parole in the United States. Section 2 presents a framework for comparing the social cost of crime under parole and under a fixed-sentences regime. Section 3 describes the Georgia data and demonstrates that this sample of prisoners is similar to the U.S. prison population along several key dimensions. Section 4 estimates the effect of prison time on recidivism rates. Section 5 examines the accuracy of parole boards in conditioning release dates on inmates' recidivism risk. Section 6 evaluates inmates' sensitivity to the incentives provided by parole in terms of their behavior and investment while in prison and their recidivism after release. Section 7 uses the empirical results to calculate the social cost of crime under a parole and under a fixed-sentences regime and then offers concluding remarks.

\section{A brief history of parole in the United States}

From the late 1880 s — when prison policy was first centralized by state governmentsuntil the 1980s, inmates in nearly every state as well as the federal prison system were subject to the discretion of a parole board. ${ }^{3}$ Parole was an integral part of a criminal justice system committed to rehabilitation; differences in the rates at which inmates proceeded through the rehabilitative process necessitated a discretionary authority to determine when each inmate was ready to rejoin society. In the $19^{\text {th }}$ century, parole was often justified using religious notions of

\footnotetext{
${ }^{3}$ By the time of the Great Depression, only four states did not have explicit laws authorizing parole. See Abadinsky (2003) for more information on the history of parole as well as American corrections more generally.
} 
redemption whereas justifications in the $20^{\text {th }}$ century relied more on science and medicine, but the commitment to rehabilitation remained. ${ }^{4}$

Beginning in the 1970s, criminologists and policy-makers on the left began to lose faith in the rehabilitative model, which, after all, required granting vast discretionary power to a government that had produced the Vietnam War and Watergate. ${ }^{5}$ The left's disillusionment aligned them with those on the right, such as J. Edgar Hoover, who had long questioned the efficacy of rehabilitation and parole. With no strong political constituency remaining, parole was replaced in state after state with truth-in-sentencing laws mandating that inmates serve a set share of their sentence. ${ }^{6}$ The federal government also took steps to eliminate parole and to encourage the states to do the same; after 1984, those sentenced in federal court were no longer eligible for parole, and in 1994 Congress authorized additional funding for states that required violent felons to serve at least 85 percent of their original sentences. ${ }^{7}$ Figure 1 shows the steady decline since 1980 in the share of inmates released via a parole-board decision. ${ }^{8}$

\footnotetext{
${ }^{4}$ American correctional institutions were born during the Third Great Awakening and religious leaders played a key role in formulating policy. Reverend Frederick Wines, who in New York during the 1860s directed the first stateauthorized parole system, wrote: "Criminals can be reformed ... reformation is the right of the convict and the duty of the State...that time must be given for the reformatory process to take effect, before allowing him to be sent away..." (Abadinsky 2003, p. 215). Policy makers took on a more scientific tone in the $20^{\text {th }}$ century: "This new approach to criminal behavior stressed deviance as pathology ... [The criminal] should be helped to understand his unconscious motivation and to go through a process of psychoanalytical change" (Robitscher 1980, p. 44).

${ }^{5}$ Martinson (1974) offered an influential meta-analysis of studies on rehabilitation that led to the so-called "nothing works" philosophy of corrections (Cullen 2004). However, Cullen also argues that political and ideological factors were equally important in criminologists' giving up on rehabilitation: "Criminologists, it seems, were politicized by the events of that day - by a Civil Rights movement that did not achieve all its goals and left racial inequality intact, by the waging of the Vietnam War, by the shootings at Kent State and Attica, by the Watergate scandal...Because the rehabilitation justified giving 'the state' - judges and correctional officers-near unfettered discretion to individualize interventions, criminologists took special aim at rehabilitation" (Cullen 2004, p. 254).

${ }^{6}$ The exact date of release may be left up to the diminished discretion of parole boards or calculated via a behaviorbased formula known as "good time."

${ }^{7}$ The funding was known as the Violent Offender Incarceration and Truth-in-Sentencing Incentive Program and was part of the Crime Act of 1994. Sabol et al. (2002) provide an excellent overview of the law, concluding that the grants themselves were largely symbolic and at most merely encouraged an already robust trend at the state level away from parole-board discretion.

${ }^{8}$ It should be noted that the abolition of parole did not mean the abolition of post-prison supervision (sometimes referred to as "the other parole"). While many states eliminated the role of parole boards, the role of parole officers
} 
The abolition of parole was initially popular with voters, but public opinion is currently mixed and some states are considering a return to traditional discretion. Virginia and Mississippi have repealed their truth-in-sentencing laws for certain low-risk populations and Wisconsin is considering similar measures (King and Mauer 2002). The nascent movement to reconsider discretion is part of a larger movement to get "smart" as opposed to just "tough" on crime (Swope 2002). The cost of incarcerating a growing prison population-the number of incarcerated Americans has increased from 500,000 in 1980 to more than two million in 2006put a strain on state budgets even in the 1990s, when they generally enjoyed substantial revenue growth; the economic downturn since 2000 has exacerbated the situation. ${ }^{9}$ For the first time in decades, states appear to have put parole-board discretion back on the table.

\section{A framework for comparing parole and fixed-sentence regimes}

Consider an individual who has been convicted of a crime. The social cost of his trial and (assuming he is guilty) of the crime itself are already sunk, but he may still impose future costs on society: first, the food, shelter and supervision the state must provide while he is incarcerated, and second, the social cost of any crimes he commits after his release. This section compares the sum of these two costs under two policy options: a discretionary parole board and a fixed-sentences regime that sets the date of release at the time of sentencing.

remained largely unchanged. Inmates were still required to report to parole officers upon release and submit to their requests (such as regular meetings, drug tests and proof of employment). See Petersilia (1999).

${ }^{9}$ The increase in the U.S. incarceration rate has been widely studied by economists and other researchers, and has been linked to parole and sentencing reform (Sabol et al. 2002, Schumertmann et al. 1998) and the increased use of prison - instead of other forms of punishment such as probation-to punish offenders (Western 2006), especially drug offenders (Kuziemko and Levitt 2004). 


\section{The basic framework}

Figure 2a illustrates a simple framework for determining the optimal time of release. Each day, a cost-minimizing social planner compares the social cost of incarcerating an inmate to the social cost of releasing him. The planner lets him go on day $t^{*}$, when the two social costs are equal. The figure shows that after this day incarceration would be more socially costly than release. $^{10}$

The analysis in Figure 2a makes several assumptions. The first assumption is that the marginal social cost of incarceration does not change with time in prison. This approximation appears to be reasonable because many of the costs associated with incarceration—food, clothing, shelter, security—are fairly constant. There are caveats, however. First, guards note that inmates are most difficult to manage when they first arrive. ${ }^{11}$ Second, due to health care costs, the annual cost of incarcerating an elderly prisoner is three times that of the average inmate (Petersilia 2006). However, these exceptions represent a small share of the general prison population.

The second assumption, that the marginal social benefit of incarcerating an inmate (or, equivalently, the marginal social cost of releasing him) declines with time served, is more complicated. ${ }^{12}$ That prison time displays diminishing returns depends on the time-path of the key social benefits associated with incarceration: incapacitation, rehabilitation, and deterrence (Western 2006). The incapacitation benefit of an additional year in prison arises from the fact that incarceration effectively eliminates the possibility that an inmate can endanger those outside

\footnotetext{
${ }^{10}$ See Appendix A for a formal model justifying the graphs and intuition used in this section and Appendix B for social-welfare calculations. The model at first takes effort as given but later relaxes that assumption and treats parole as a contracting problem.

${ }^{11}$ Personal correspondence with officials in the Georgia Department of Corrections and Oregon Department of Corrections.

${ }^{12}$ Although this assumption need not always hold, it is the only interesting case; if the social cost of release were constant or increasing, a knife-edge solution would hold in which a criminal would either not be incarcerated at all or would be held until death.
} 
of prison. It can be approximated by the annual probability that the inmate will recidivate multiplied by the cost society incurs if he recidivates. If an inmate's probability of recidivism falls with time in prison, then the incapacitation component of the marginal social benefit curve will also fall with prison time.

Whereas the incapacitation benefit depends on the level of an inmate's recidivism risk, the rehabilitation benefit depends on the derivative of the recidivism function with respect to time. The rehabilitative value of a marginal year of incarceration depends on the decrease in recidivism, had the inmate been incarcerated for that year. Thus, if the effect of prison time on annual recidivism risk were negative but diminishing, the rehabilitation benefit of a marginal year of incarceration would decline with time served. In Section 4, I will investigate empirically whether these assumptions about the shape of the recidivism curve holds.

The final benefit of keeping inmates incarcerated is that it may deter prospective criminals from committing crimes. The existing literature contains a range of estimates on the deterrent effect of increasing punishment. ${ }^{13}$ Whatever the magnitude of the deterrence effect, it is likely to be decreasing with time served: increasing the length of time served from one to two years should have a greater deterrence effect than increasing the length from ten to eleven years.

\section{Comparing rules and discretion}

In a world with perfect information and no heterogeneity across inmates, the choice of regime does not matter. This scenario has already been depicted in Figure 2a. An optimal

\footnotetext{
${ }^{13}$ For a general review of empirical estimates of the deterrent effect of expected punishment, see Levitt (2004). Kessler and Levitt (1999) use aggregate crime rates to show that criminals are indeed sensitive to expected punishment as they substitute away from crimes whose sentences have been raised. But Lee and McCrary (2005) use individual panel data to demonstrate that the criminal activity of teenagers does not respond to expected punishment (their crime rates do not fall once they turn 18 and are subject to longer sentences).
} 
sentencing rule and a fully informed discretionary authority both would give $t^{*}$ as the release date.

Now suppose instead that there are equal numbers of two types of inmates, as in Figure 2b. A social-cost-minimizing parole board with perfect information would release the low-risk types at $t^{\mathrm{L}}$ and the high-risk types at $t^{\mathrm{H}}$. A rule-maker who cannot observe inmate type would set a single release time where the average of the two marginal benefit curves meets the cost curve, at point $t^{\mathrm{R}}$, resulting in deadweight loss equal to areas $\mathrm{A}+\mathrm{B}$.

Figure $2 \mathrm{~b}$ implicitly assumes that the relationship between time served and recidivism risk is identical across the two regimes, but this assumption may not hold. Figure $2 \mathrm{c}$ shows how, relative to a rules regime, parole may provide incentives for inmates to invest in their own rehabilitation. When inmates take steps to lower their recidivism risk in a rules-based regime, they still serve $t^{\mathrm{R}}$. However, as the figure shows, time served in a discretionary regime falls when the expected risk declines (shifts to the left), as it presumably would when an inmate increases investment in rehabilitation. As the inmate now represents less of a threat, the marginal social benefit of incarceration falls and his optimal release date is earlier. ${ }^{14}$ Of course, inmates have a reason to invest even if they are not eligible for parole, since investment today may increase future wages and reduce the probability of future imprisonment (as in a classic Becker-Rosen-style model of human capital). But, as Figure $2 \mathrm{c}$ shows, the parole board can amplify these incentives by conditioning early release on inmates' investment behavior.

\footnotetext{
${ }^{14}$ Of course, the choice of regime might also shift the cost curve, though the direction is unclear. On the one hand, inmates' demand for rehabilitative programs might increase, making incarceration more costly; but to the extent that programs currently exist and are just underutilized, this effect should be small. On the other hand, inmates who are seeking to impress a parole board will have a greater incentive to avoid disciplinary infractions, making incarceration less costly. In any case, compared to the daily costs of food, shelter, and supervision, these changes should be small.
} 
The differences just described between a parole-board system and an ex-ante rules-based regime hinge on the parole board's ability to condition an inmate's release date on his future recidivism risk. The welfare gains depend on both the board's ability to predict future recidivism and their steadfastness in using recidivism (and not some other criterion) to determine release dates. Parole boards must be able to distinguish between inmates making real progress towards rehabilitation from those who are merely going through the motions. They must also share the objective function of society or they will create welfare loss by, say, systematically releasing inmates too early-the chief concern of most truth-in-sentencing proponents.

In the remainder of the paper, these and other key assumptions of the framework will be investigated empirically.

\section{Data}

I rely chiefly on administrative records from the Georgia Department of Corrections (GDC) because the state's prison data are rich and because several policy shocks and institutional features of the state's criminal justice system provide useful quasi-experimental sources of variation to identify the key parameters of the framework. The GDC manages an "inmate data file" that covers every inmate who served time in a state prison since 1975 . This data set provides standard criminal-justice variables including demographic information, criminal history, current sentence, and measures of future recidivism.

Inmates in the Georgia data appear to be representative of the national prison population in many key ways. In 1997, for instance, offenders convicted of violent crimes composed $47.3 \%$ (48.5\%), and offenders convicted of drug crimes composed $20.6 \%$ (18.6\%), of the national (Georgia) prison population. Both populations in that year had the same average age at 
admission (31 years), although Georgia inmates released in 1997 served an average of 24

months-three months less than the national average. ${ }^{15}$ Furthermore, inmates released in

Georgia faced a similar labor-market environment as those in the rest of the country. ${ }^{16}$

Table 1 displays summary statistics for inmates admitted between 1980 and 2004. I limit the sample to those who are (1) new court commitments, (2) at least 18 years old at the time of admission, (3) sentenced to between 6 and 120 months, and (4) already released. The first two conditions are commonly used in the economic literature on crime. ${ }^{17}$ I impose the third condition because the sources of exogenous variation that I am able to exploit exist only in this sentence range and I want to avoid creating comparison groups with much longer sentences. The fourth condition is necessary to observe recidivism.

Table 1 gives a general sense of the prison population in the resulting sample. About 30 percent of inmates return to prison within 36 months of their release (a standard definition of recidivism that I will use throughout the paper). ${ }^{18}$ The average inmate served about 29 months in prison, had an original sentence of about six years and was convicted of about 1.5 felonies before the current conviction for which he is serving time.

\footnotetext{
${ }^{15}$ National prison statistics are published annually by the U.S. Bureau of Justice Statistics. I choose 1997 as it is the mean year for much of the analysis in the paper. The numbers are based on summary statistics from the GDC data and U.S. Bureau of Justice Statistics (1998).

${ }^{16}$ Throughout the 1990s, Georgia's unemployment rate trended with the national rate and the absolute difference between the two rates was never more than one percentage point (Statistical Abstract of the United States, various years).

${ }^{17}$ New court commitments are those inmates who are serving a prison sentence as a result of a conviction in court, as opposed to those who violated probation or parole.

${ }^{18}$ Other definitions of recidivism include re-arrest or reconviction within a certain period of time. I do not have rearrest data, but results using reconviction as the dependent variable are available upon request. The chief difference between the return-to-prison variable I use and the reconviction variable is that the latter does not define those returning to prison on a technical violation of parole as having recidivated. However, parole officers and prosecutors often arrange for those who had committed new crimes to merely be "violated" in order to ensure that they are back in prison and to avoid new trials. In fact, Austin and Lawson (1998) estimate that $82 \%$ of parole violations have an underlying criminal charge associated with them.
} 


\section{The effect of prison time on recidivism risk}

What is the effect of the length of time served on an inmate's future criminal propensity? Proponents of longer sentences suggest several mechanisms by which more time in prison might reduce recidivism. First, a longer prison spell might "scare someone straight." Surveys show that a large majority of inmates agree that prison "taught them a lesson" and that they "have given up criminal activity forever" (Van Voorhis et al. 1997). According to this "specific deterrence" hypothesis, punishment deters the offender from committing future offenses, and this effect is believed to increase with the length of the prison spell. ${ }^{19}$ Longer prison spells might also expose inmates to more rehabilitative and educational programming: according to this hypothesis, inmates avoid prison after release not because they fear returning but because they have more marketable skills in the legal labor market, making criminal activity relatively less attractive. Finally, an inmate's ties to criminal associates "on the outside" might diminish with time "inside," preventing him from falling in with his old crowd upon release.

But longer prison spells might also have deleterious effects on inmates. First, constant contact with other offenders could increase an inmate's criminal capital. Second, longer exposure to potentially dehumanizing prison conditions could lead to a rougher transition back to the outside world. Third, inmates serving longer terms may lose contact with family members, former employers, and other potentially stabilizing influences. ${ }^{20}$

\footnotetext{
${ }^{19}$ Specific deterrence is distinct from general deterrence and refers to the effect of the punishment on the future criminal activity of the specific person being punished (e.g., being "scared straight" after spending time in prison). Becker (1968) explains the notion of general deterrence: punishment can also affect the crime rate of the nonincarcerated population because it lowers the expected benefit of criminal activity. Only those who have already been punished can be specifically deterred, whereas anyone can be generally deterred.

${ }^{20}$ Evidence on the effect of prison on recidivism is mixed. Bayer, Pintoff and Pozen (2004) find that an offender who serves time with inmates who have committed the same crime he did will further specialize in that crime. Katz, Levitt and Shushtorovich (2003) use variation across states and years in prison conditions (proxied by prison deaths per state per year) and find that prison conditions are negatively associated with crime rates, consistent with poor prison conditions deterring criminals (either through specific deterrence via lower recidivism rates or through general deterrence if the unpleasant conditions are well known throughout the population of potential criminals).
} 
Existing studies have produced no clear consensus on the impact of time served on future criminality. In its multi-state study on recidivism in 1994, the Department of Justice found mixed evidence on the relationship between time served and recidivism rates. In a meta-analysis of 325 estimates of the effect of time served on recidivism, Gendreau, Goggin, and Cullen (1999) also failed to emerge with any consensus. In related work on whether longer sentences hurt future labor-market outcomes, Kling (2006) finds essentially no effect of time served. To the extent that any conclusion can be drawn from the existing literature, it is that current estimates are noisily estimated but appear to be close to zero.

Yet evidence suggesting that the effect of time served on recidivism is negligible should be interpreted with caution. As most of the studies rely on OLS estimation, the estimated coefficient is a combination of selection and treatment effects. ${ }^{21}$ Conditional on a given sentence, those who serve more time receive harsher treatment from parole boards. If parole boards assign those with higher recidivism risk to longer prison terms, then the selection effect of longer terms on recidivism will be positive and OLS estimates of the treatment effect of time served will be positively biased.

To remedy this situation, I exploit several sources of plausibly exogenous variation in the length of time served in order to identify the treatment effect.

Chen and Shapiro (2006) use a regression-discontinuity design generated by the cut-off ruls used to assign federal inmates to different security levels. They find that assignment to minimum-security prisons lowers future recidivism risk.

${ }^{21}$ An exception is Kling (2006), who uses the sentencing propensity of randomly-assigned judges as an instrument for time served as well as matching on observables; both methods suggest that there is little effect of time served on labor-market outcomes." 


\section{The "mass-release" identification strategy}

On March 18, 1981, the governor of Georgia ordered the state's Department of Corrections to free up more than 900 beds in order to reduce overcrowding in local jails. The GDC ranked its current non-violent inmates by day of prospective release (already set by the parole board) and released the first 901 on the list. Those at the top of the list had served almost all of the time the parole board recommended, but those at the bottom of the list had served considerably less time than was originally recommended. The typical inmate on the list was sentenced to about 24 months, served about 10 months, and enjoyed about 4 months off of his tentative parole date. ${ }^{22}$

It is tempting but not strictly correct to assume that time served for those inmates on the list is exogenous. Consider two inmates released on March $18^{\text {th }}$ : one who served two years and the other six months. The inmate who served two years had a sentence at least that long, whereas the one who served six months could have been sentenced to only six months and served all of his time (i.e., he was at the top of the list), or he could have been sentenced to two years and received a considerable reduction (i.e., he was at the bottom of the list). In the former case, he is a poor comparison for the first inmate as ideally one wants to compare inmates who have the same original sentence.

Conditional on having the same sentence length, the only reason why two inmates released on the mass-release day would have difference lengths of time served is that one committed his crime (or began serving his sentence) on a different date than the other. Thus, the identifying assumption on which I rely is that the exact date on which an inmate begins his sentence is exogenous.

\footnotetext{
22 Technically, the GDC subtracted one year from the sentences of all non-violent inmates, which resulted in immediate release for the first 901 inmates listed in order of prospective release date.
} 
I cannot test this assumption directly as the variables "date crime was committed" and "date sentence was started" are usually missing from the data during this period. ${ }^{23}$ Instead, I regress several variables thought to be related to recidivism on time served and original sentence. In regressions of prior incarcerations, age at release, age at first contact with the criminal justice system, and an indicator variable for being black, the coefficient on time served is never significant. ${ }^{24}$ Thus, conditional on original sentence length, time served appears plausibly exogenous.

Col. (1) of Table 2 shows the results from a naive OLS regression using the "mass release" sample in which unconditional time served is assumed to be exogenous. The dependent variable (for this and all other recidivism regressions unless otherwise noted) is an indicator for whether the inmate returned to prison within three years of his release; the explanatory variables include length of time served and standard demographic and criminal-history controls. The coefficient on time served is weakly positive, consistent with a positive bias caused by the fact that inmates with greater criminal tendencies receive longer sentences.

Col. (2) adds fixed effects for sentence length. ${ }^{25}$ By controlling for the variation in time served due to sentence length, this estimation uses only the variation arising from the date the sentence started. Eliminating the possibly endogenous variation due to sentence length has remarkable effects: the sign on the coefficient of interest is now negative and statistically significant. The point estimate suggests that for each extra month served, recidivism falls by about one percentage point ( 3 percent).

\footnotetext{
${ }^{23}$ One cannot "back-out" the date the crime was committed or the date the sentence commenced from the date of release and the amount of time served, since an inmate does not start serving his sentence until his arrest (if he cannot post bail and thus has his pre-trial jail time credited towards his sentence) or sentencing (if he is able to post bail). Information in the GDC data on the dates of crime and sentencing improves only in the 1990s.

${ }^{24}$ Regression results available upon request.

${ }^{25}$ Sentence fixed effects are constructed by rounding each inmates sentence to the nearest multiple of twelve and then including dummy variables for each of the values of the rounded sentence measure. More than $75 \%$ of all observations have a sentence length that is a multiple of twelve months.
} 
Col. (3) adds a control for how much time the inmate would have served had the parole board's recommendation been followed. While most of the variation in time served is driven by sentence length and the date the sentence began, the decision of the parole board will also determine who made the cut-off for the mass-release list. This estimation strategy, therefore, compares two inmates with the same sentence, the same parole-board recommendation, but different lengths of time served due to the start-dates of their sentence. Adding this control only strengthens the result: the coefficient suggests that for each extra month served, the probability of recidivism within three years of release falls by about 2.5 percentage points.

Col. (4), my preferred specification, excludes observations for which time served is more than three standard deviations from the mean. This adjustment also increases the effect of time served on recidivism. The remaining columns contain robustness checks for the result in Col. (4). I add fixed effects for offense groups in Col. (5) and the results do not change appreciably. ${ }^{26}$ Finally, Col. (6) reports regressions from a Cox proportional hazard model, with failure defined as returning to prison. The odds ratios are all consistent with the changes in probability measured in the previous columns.

Given a baseline probability of recidivism of 0.37 for this sample, the results in Col. (4) suggest that every extra month in prison reduces the probability of recidivism by about seven percent. There are several reasons why this large effect may not generalize to the typical prison population. First, the mass release surprised prisoners and prison personnel—released inmates were literally told the good news the morning of their release. Those receiving the largest breaks may have been the least emotionally or practically prepared for their release and —-to the extent that personnel devise educational, counseling and training curricula based on how long they expect to work with the inmate-their rehabilitative programming would have been cut the

\footnotetext{
${ }^{26}$ Although there are a total of 38 such groups, only 18 of them are represented in the mass-release sample.
} 
shortest, negatively biasing the estimate of the coefficient on time served. ${ }^{27}$ Second, the nature of the release might lead to unusual specific deterrence effects. Those inmates fortunate enough to receive a large reduction from their expected time served might form the impression that the criminal justice system is generally lenient and thus be less deterred in the future. Finally, only non-violent offenders were released because of the mass-release order.

For these reasons, I now turn to a different identification strategy in an attempt to verify the above results.

The "grid" identification strategy

When an inmate arrives in a Georgia state prison, he receives a point designation from 1 to 20 based on pre-determined characteristics such as age and past record. As Appendix Table C1 shows, the point designation, along with the inmate's conviction charge, can be used to generate a recommended prison term. While parole boards remain free to adjust this "grid" recommendation up or down, it serves as a useful baseline and is often ( 28 percent of the time) followed without modification and is usually (64 percent of the time) within four months of the board's final decision. The grid does not use the exact score but instead assigns inmates to lowrisk (14 to 20 points), medium-risk (9 to 13 points), and high-risk (1 to 8 ) groups. Such cut-offs suggest a regression discontinuity design; criminal propensity should vary in a roughly continuous manner across scores, but the recommendation varies in a highly discontinuous manner. Moreover, as the grid assigns higher-risk inmates to longer sentences, any bias would go against confirming the mass-release results.

\footnotetext{
${ }^{27}$ Georgia did not record enrollment in prison educational and rehabilitative programming until the 1990s, so this hypothesis cannot be directly tested.
} 
Figure 3a shows how time served varies across different point levels. Boards appear to roughly follow the recommendations of the grid, especially around the first threshold. Figure $3 \mathrm{~b}$ shows that the number of prior convictions (a covariate traditionally thought to be important in determining recidivism and that indeed has a large coefficient in all of the estimations shown in Table 2) displays no such break at the score thresholds. Similarly, age and share black show no discontinuities at the cut-offs points, though I do no present these graphs in the interest of space. Figure 4 focuses on those inmates near the first cut-off. The figure displays the share of inmates returning to prison as a function of months since release, plotted separately by score. As would be expected, those with ten points have lower recidivism than those with nine, and those with eight points have lower recidivism than those with seven. However, comparing those with eight and nine points reveals a break in the pattern. While those with eight points are predicted ex ante to have higher recidivism risk, those with nine points have higher ex post recidivism rates. Recall that these two groups receive very different treatment: those with nine points serve about 2 months (10 percent) less. As the groups with eight and nine points depart from the predicted monotonic decrease in recidivism, and those groups are also on different sides of the threshold, the figure suggests that there might indeed be a negative treatment effect of time served on recidivism.

Table 3 examines the above results in a regression framework. Col. (1) shows the naive OLS regression, in which the coefficient on time served is negative but small in magnitude. Col. (2) shows the IV results. The first-stage estimate is based on a standard set of controls (see notes to Table 3), fixed effects for the year of release, as well as an indicator for whether an inmate has a score above eight points, an indicator for whether the inmate has a score above 13 points, and a quartic function of points. I exclude the indicator variables in the second stage on the 
assumption that the 8- and 13-point cut-offs have no independent effect on recidivism outside of their effect on time served (note that the quartic function remains in the second stage to control for any continuous variation in the propensity to recidivate captured by points). The coefficient suggests that for every additional month in prison, recidivism falls by 1.4 percentage points ( 3 percent).

Col. (3) adds offense fixed effects without any noticeable change in the results. Col. (4) zeros in on the first threshold, as it appears from Figure 3a to be the more viable experiment. The point estimate remains negative and substantially increases in magnitude. Finally, Col. (5), my preferred specification, uses a more stringent identification strategy. Instead of merely controlling for points with a continuous function in the second stage, the specification includes fixed effects for points and uses in the first stage the actual recommendation from the grid. Thus, the identification is coming merely from the interaction between points and crime severity level, and all the main effects remain in the second stage. The coefficient is smaller in magnitude, but still negative and significant.

\section{Differential and non-linear treatment effects}

Table 4 shows how the treatment effect (as estimated in the fully-interactive model in the last column of Table 3) varies across different sub-samples of the data. Col. (1) shows a similar effect for older and younger inmates. Criminal propensity falls with age for younger offenders but flattens out after age twenty-five (Hirschi and Gottfredson 1983), suggesting that, at least for older offenders, the results cannot be explained by a mere "aging out" effect. Cols. (2) and (3) suggest that the recidivism of first-time offenders and drug offenders are less sensitive to time served. As prison time does not appear very effective in rehabilitating these groups, the results 
are at least consistent with efforts to develop alternative sentences for such offenders (Taylor-

Thompson 2000).

All of the regressions in Tables 2 and 3 assume a linear relationship between time served and recidivism. Such a functional form appears unlikely, if only because it would predict negative recidivism values for those serving very long prison terms. The last column of Table 4 shows how the effect of time served varies locally. For those serving 20 months or less, an extra month decreases recidivism by more than two percentage points, but an extra month has close to no effect on those serving more time, suggesting a diminishing ability of prison time to decrease recidivism.

However, the estimates in Col. (4) cannot prove concavity of the treatment effect, as the short-run effect and the long-run effect are being estimated off of disjoint populations. Increasing time served, regardless of the baseline value, could have a larger effect on the type of inmate who generally serves short terms than on the type of inmate who generally serves long terms, so that selection, not a non-linear treatment effect, is driving the result. Estimating the second-order properties of the relationship between time served and recidivism requires a population that is at risk of random assignment at two distinct neighborhoods of the time-served distribution. $^{28}$

A possible non-linear treatment effect does reconcile the differences in the magnitudes found in the mass-release (Table 2) and the grid (Table 3) experiments. As those inmates who left prison on the mass-release day served ten months on average, they are best compared to

\footnotetext{
${ }^{28}$ For example, an inmate would first be randomly assigned to one of two groups: those who serve an average of 24 months and those who serve an average of 12 months. After the first randomization is realized, inmates are then randomly assigned to either a decrease or increase of three months from their assigned average sentence. Such a design would allow a credible estimate of the local treatment effect in two different neighborhoods of the timeserved distribution. However, such a design involves an initial random assignment to two very different treatments-a situation one would hope not to encounter in a system of uniform justice.
} 
those serving less than 20 months in the grid-experiment data. The first point estimate in Col. (4) of Table 4 and those found in Table 2 are remarkably similar.

In summary, all point-estimates arising from quasi-experimental variation in Tables 2 and 3 are negative and statistically significant, and are similar in magnitude even across different samples and different identification strategies. Furthermore, sub-sample results suggest that the effect of prison time on recidivism is diminishing. The assumption made in Section 2 that the effect of prison time on recidivism is negative but diminishing appears consistent with all the empirical results in this section.

\section{Do parole boards condition release on inmates' recidivism risk?}

For a parole regime to increase inmates' incentives to invest in their own rehabilitation, parole boards must be able to sort inmates by recidivism risk and must reward low-risk inmates with shorter prison terms. If parole boards condition early release on inmates' having lower recidivism risk, then those with longer recommended terms should, all else equal, have higher expected values of recidivism at the time the decision was made. But, as only actual recidivism can be observed in the data, a case of classic simultaneity arises: the length of time the board recommends should increases with recidivism risk, but then the length of time affects observed recidivism (the results in the previous suggest recidivism falls with time served). ${ }^{29}$

To see this, let recidivism $R_{i}=r_{i}-\beta t_{i}$, where $r_{i}$ denotes initial recidivism risk (unobservable to the econometrician but possibly observable to the parole board), $t$ time served, and $\beta$ the treatment effect of time served. Suppose parole boards use recidivism risk as an

\footnotetext{
${ }^{29}$ It is tempting idea to view the OLS estimate of the effect of time served on recidivism as the sum of a treatment and a selection effect, and therefore to subtract from it the treatment estimates from Section 4 to get the selection effect. But the heterogeneity of the treatment effect found in the previous section implies this approach is not credible (see Angrist 2004).
} 
estimate for the marginal social benefit of incarceration and suppose further that, as in Section 2, the marginal social cost is constant. ${ }^{30}$ Equating the marginal cost and benefit implies that parole boards will set $t_{i}^{*}$ so that all inmates leave with the same expected recidivism risk, say, $K$. This optimization implies that $r_{i}=K+\beta t_{i}^{*}$ and substituting back into the recidivism equation yields $R_{i}=K+\beta t_{i}^{*}-\beta t_{i}$.

The prediction that time served and recommended time served should have coefficients of equal magnitude but opposite sign is difficult to test empirically because, in general, $t^{*}$ and $t$ are identical (inmates serve however much time the parole board recommends), making simultaneous estimation of the coefficients on both variables impossible. Although deviations exist—for example, an inmate's release can be delayed if he does not have his required paperwork completed—-they do not appear to be random departures.

\section{Using the mass release experiment}

Ideally, one would like to record the parole boards' recommendation but then have prisoners released in a manner independent of the recommendation. A severing of the recommended and actual release dates would allow for direct estimation of the relationship between the recommendation and recidivism. The mass release experiment provides just such an opportunity. Parole boards made their recommendations assuming that they would be followed in the usual manner, but then the overcrowding crisis intervened to void those recommendations. Because the recommendations were recorded but not implemented, it is now

\footnotetext{
${ }^{30}$ Recall from Section 2 that recidivism risk need not be the only element of the social benefit of incarceration. Deterrence and rehabilitation are also possible benefits. However, it appears that parole boards view recidivism risk as the key factor, perhaps because it is easier to observe. My reading of parole-board mission statements suggest that they are almost exclusively concerned with protecting the public by releasing only those inmates whose recidivism risk is sufficiently low.
} 
possible to test the prediction that the coefficients on actual and recommended time served should be equal in magnitude but opposite in sign.

These estimates have already been calculated, in fact. Cols. (3) - (5) of Table 2 show how recidivism varies with time served and with recommended time served. Comparing the coefficient on time served and the coefficient on the parole board's recommendation in Table 2, it appears that parole boards indeed assign prison time so as to equate inmates' expected recidivism upon release. The preferred estimates in Col. (4), for example, suggest that each month served decreases the probability of recidivism by about 3.0 percentage points, whereas each extra month the parole board assigns is associated with a 2.8 percentage-point increase in the probability the inmate will recidivate. In Col. (5), the magnitudes of the coefficients are almost identical.

\section{Do parole boards use all available information?}

Another test of whether the parole board is making efficient use of information is to compare the informational value of observables in predicting recidivism when parole boards have discretion and when they do not. If parole boards use their discretion to assign more time to those who continue to have high expected recidivism rates and less time to those who are no longer dangerous, then observable variables should have little predictive power, as boards should have already used the information so as to limit the variance of expected recidivism upon release.

To test this hypothesis, I compare situations in which the parole board appeared unconstrained in its decision to situations in which it appeared relatively constrained. As parole boards generally do not interview an inmate until about a quarter to a third of his sentence has 
been completed, there is a lower bound on the amount of prison time they can assign. ${ }^{32}$ Conversely, because they cannot assign terms that exceed the judge's sentence, their recommendation also has a strict upper bound.

Figure 5 plots the pseudo-R-squared values from probit regressions of recidivism on a standard set of observables (the control variables reported in Tables 2 and 3 ) against the recommendation of the parole board as a share of the original sentence. As argued above, parole boards are likely to be most constrained when they make either very low or very high recommendations. Indeed, Figure 5 shows that the R-squared value rises as the ratio of parole board recommendation to original sentence approaches both the upper and lower boundaries.

In summary, parole boards' recommendations appear to offset inmates' initial recidivism risk. When parole boards are unconstrained, they use the information available to them in an efficient manner, such that the explanatory power of observables is nearly all accounted for and most of the variation in whether an inmate recidivates or not is unpredictable. When parole boards are constrained, on the other hand, some observable predictors of recidivism remain unused and information appears to be "left on the table."

This conditioning of release on expected recidivism should increase the efficiency of correctional institutions by freeing up beds occupied by the lowest-risk inmates. Moreover, releasing inmates when they reach a certain threshold should provide incentives for prisoners to invest in their own rehabilitation so as to reach the threshold sooner. The next section investigates whether inmates react to such incentives.

\footnotetext{
${ }^{32}$ This information comes from conversations with the staff at the GDC. Unfortunately, no clear rule exists and some inmates are seen earlier. Hearing dates are not in the data set.
} 


\section{The effect of parole board discretion on inmate behavior and recidivism}

In general, inmates have two types of incentives to invest in rehabilitation while in prison. The first is the return on classic Becker-Rosen style human capital; by, say, taking vocational classes, inmates may lower their probability of returning to prison and increase their wages in the legal labor market. The second is generated by parole boards' discretion; when inmates engage in rehabilitative activities, parole boards observe their reduced risk and release them from prison sooner. This section tests the hypothesis that when the second type of incentive is removed, inmate investment in rehabilitation falls and recidivism rises.

\section{Georgia's $90 \%$ reform}

In 1997, the parole board announced that all inmates convicted of certain offenses after December $31^{\text {st }}$ must serve at least $90 \%$ of their sentence. ${ }^{34}$ It maintained the power to assign inmates convicted of a "90\% crime" to release dates between 90 and $100 \%$ of their original sentences and full discretion over inmates convicted of all other crimes. Although the specified offenses included such sensitive crimes as child molestation and statutory rape, the majority of those affected by the policy were convicted of robbery and assault. ${ }^{36}$

Figures $6 a-d$ suggest that the $90 \%$ reform offers the rare opportunity to study the effect of a statutory change in discretion that did not have large effects in terms of average punishment. These figures show the trends between 1993 and 2000 in several key variables related to time served, graphed separately for inmates in the treatment ("90\%") group and for those in the

\footnotetext{
${ }^{34}$ According to discussions with Dr. Tim Carr (GDC), the legislature's threat to pass a law to this effect likely precipitated the board's decision.

${ }^{35}$ The crimes specified in the $90 \%$ reform were child molestation, statutory rape, aggravated assault or battery, carjacking, attempted murder, assault on police officer, incest, attempted rape, manslaughter, or robbery. Assault and battery accounts for $35 \%$ of such cases and robbery for $22 \%$.

${ }^{36}$ The crimes specified in the $90 \%$ reform were child molestation, statutory rape, aggravated assault or battery, carjacking, attempted murder, assault on police officer, incest, attempted rape, manslaughter, or robbery. Assault and battery accounts for $35 \%$ of such cases and robbery for $22 \%$.
} 
control group (inmates who did not commit $90 \%$ crimes but who met the conditions described in Section 3 and had sentences between 20 and 60 months). ${ }^{37}$

Figure 6 a tracks time served as a share of the original sentence for the median inmate in each group. The reform had little effect on this ratio, as most inmates in the treatment group had been serving close to $90 \%$ of their sentence even before 1998 . Figure $6 \mathrm{~b}$ tracks the $10^{\text {th }}$ percentile of "percent of original sentence served"- thus focusing on those who served the smallest share of their sentences. Here, there is a marked effect of the reform: the percent jumps from about $70 \%$ in 1997 to $90 \%$ in 1998.

Figure $6 \mathrm{c}$ shows that sentences for $90 \%$ crimes were gently falling over this time period, while sentences for control crimes remained flat. As time served is the product of sentence and percent of sentence served, and sentences fell slightly while percent served increased, there is only a limited increase in time served for the $90 \%$ group (Figure 6d). I do not display additional figures in the interest of space, but there appears to be no change in demographic selection into the control and treatment groups coincident with the policy change.

In summary, since the parole board already had been setting release dates to make the typical treatment-group inmate serve $90 \%$ of his sentence, the reform was not in fact binding in most cases. But even though average time served did not markedly change, the incentives to invest may have. Prior to the reform, an inmate knew that with some effort, there was a chance he would be released well before his sentence expired; after the reform, no amount of effort would achieve an early exit.

\footnotetext{
${ }^{37}$ Inmates must be released in order for their recidivism to be analyzed, but most of the inmates convicted under the 90\% law and sentenced to long prison terms were still in prison in April 2006 (the most recent date for which recidivism data have been updated). Fortunately, more than $60 \%$ of inmates in the $90 \%$ group were assigned relatively short sentences (less than five years). To avoid comparing $90 \%$ inmates with short sentences to controlgroup inmates with long sentences, most of the analysis in this section will include only those inmates with sentences between 20 and 60 months.
} 
The effect of parole eligibility on disciplinary infractions and course completions

It is not clear a priori that inmates actually respond to incentives provided by parole boards. Correctional officers have a myriad of methods for punishing bad behavior-both official (e.g., solitary confinement) and unofficial (e.g., refusing to protect an inmate from an abusive cellmate) — that could provide more powerful incentives than an adjustment in time served, which is probabilistic and delayed. As prisoners are thought to discount the future heavily (Lee and McCrary 2005), it is not clear that the possibility of a sentence reduction several years in the future would have a marked effect on current behavior.

On the other hand, although correctional officers still have any "sticks" (metaphorically speaking, one hopes) to punish prisoners, they may have lost their most important "carrot" with the limitation of parole-board discretion. Professionals in the criminal justice system, even those traditionally supportive of get-tough-on-crime policies, argue that parole is a valuable tool in managing prison populations. The United States Attorney in Georgia links the end of parole to heightened violence in the federal prison system ("The increase in violence in the prisons is not one of America's great mysteries...[Inmates] are serving longer sentences and they feel they've got nothing to lose" (New York Times 1999)) and the vice-president of the prison guards union in California links it to inmates' diminishing commitment to rehabilitation (“A guy knows he'll get out, and he doesn't really have to try and do anything to turn his life around" (San Francisco Chronicle 2006)).

Figures 7 and 8 lend support to these observations. The $90 \%$ reform appears to have had a small but marked effect on disciplinary incidents and course completions. Disciplinary incidents trended downward for the control group beginning in 1998, but they increased for the 
90\% group during this period. Similarly, the treatment and control groups start off tracking each other nearly perfectly with respect to course completions. However, the trends diverge at the time of the reform: starting in 1998, the treatment group's participation grows at a slower rate than the control group, suggesting that those convicted of $90 \%$ crimes had less motivation to invest in rehabilitative programming.

Table 5 shows the effect of limiting the parole board's discretion on inmate behavior in a regression framework. All regressions in Table 5 include the standard controls used in the previous sections plus year and offense fixed effects. The interaction between a dummy variable for being convicted of a 90\% crime and a dummy variable for being convicted after December $31^{\text {st }}, 1997$ is the key variable of interest. ${ }^{38}$

Col. (1) of Table 5 suggests that the reform was associated with a 0.0033 increase in the rate of disciplinary violations per month. Given that the average rate was 0.072 , the estimated effect represents a four percent increase in violations per month. Col. (2) shows that non-violent infractions drive the result, perhaps due to inmates' exerting less rational control in the case of violent infractions (the coefficient on the interaction term when the rate of violent infractions serves as the dependent variable is close to zero).

The next two columns are essentially parallel to the first two, except that the regressions consider the effects on investment in rehabilitative activities. Col. (3), a strict analogue to Col. (1) in terms of specification, suggests that the reform was associated with a -0.0085 (twelve percent, given a baseline of 0.064 ) decrease in the rate of program completion. The specification

\footnotetext{
${ }^{38}$ There is no natural way to replace the $90 \%$ group dummy with offense fixed effects because many inmates are convicted of multiple crimes. Absorbing, say, the most serious offense will not completely replace the $90 \%$ dummy as some of the $90 \%$ inmates will have committed a crime considered more "serious" than whichever $90 \%$ crime they committed.
} 
in Col. (4) is identical to that in Col. (2) except that the rate of enrollment (rather than the rate of completion) is used as the dependent variable, with very similar results. ${ }^{39}$

The effect of the reform on recidivism

Given that the reform appeared to increase disciplinary infractions and decrease participation in rehabilitative programming, one might expect that it also increased recidivism. Indeed, Figure 9 shows a marked increase in recidivism for the $90 \%$ group but no perceptible effect for the control group.

Col. (5) of Table 5 suggests that the reform was associated with an increase in the threeyear recidivism rate of 2.4 percentage points (or about 8 percent, given a baseline recidivism rate of about 30 percent). Col. (6) uses a Cox proportional hazard model instead of a linear probability model; the qualitative results and statistical inferences are unchanged.

The results in Cols. (1), (3), and (5) of Table 5 suggest that the reform was associated with a 4 percent increase in disciplinary violations, a 12 perfect decrease in the completion rate of rehabilitative programs, and an 8 percent increase in the three-year recidivism rate. As reported in the notes to the table, these results appear robust to varying sample restrictions and specifications. Taken together, the results from this section suggest that parole provides a powerful incentive for inmates to invest in their own rehabilitation and when such incentives are removed investment falls and recidivism rises. ${ }^{41}$

\footnotetext{
${ }^{39}$ Given that the underlying trends are so marked, I also add to the specification in Col. (2) an interaction between the $90 \%$ dummy and a linear and a squared term of year, but the addition makes almost no difference in the estimations.

${ }^{41}$ One explanation consistent with the results in Section 6 is that the specific rehabilitative investments explored in this paper cause recidivism to fall. However, caution should be exercised before assuming that the specific activities investigated in the paper have any direct effect on recidivism. For example, the hope of parole could lead prisoners to change their life in both observable ways (e.g., enrolling in courses and avoiding disciplinary infractions) and less observable ways (e.g., discovering religion or reconnecting with their families). If the observable changes have no
} 


\section{Social cost calculation and concluding remarks}

The results from the previous sections suggest that policymakers should consider several trade-offs when deciding between a discretionary parole system and a regime in which judges' sentences are binding. On the one hand, parole boards may systematically set time served below the optimal level; limiting parole-board discretion may correct this bias and thus increase social welfare. Indeed, increasing incapacitation appears to have been the motivation for most laws abolishing parole in the 1980s and 1990s. On the other hand, parole boards have access to information revealed after sentencing and therefore may be better than judges at forecasting inmates' expected recidivism risk. More accurate predictions should facilitate the release of inmates who no longer pose great risk and thus create prison capacity at low opportunity cost. Furthermore, tying early release to expected risk may allow parole boards to incentivize current inmates to invest in their own rehabilitation, decreasing the future social cost they will impose upon release.

In this paper, I have attempted to quantify these effects. Section 4 finds a strong treatment effect of time served on recidivism: each month spent in prison appears to decrease the probability of recidivism by about 1.5 percentage points. Section 5 provides evidence that parole boards are highly accurate in tying release dates to inmates' recidivism risk. Section 6 suggests that inmates under the discretionary authority of a parole board invest more in their rehabilitation while in prison (disciplinary infractions are 4 percent lower and educational and

effect but the unobservable (at least to the researcher) changes in fact reduce recidivism, then the same pattern of results seen in this section could be produced. Indeed, the mechanism by which rehabilitative investment in prison affects future recidivism remains an open question. Tyler and Kling (2006) find a limited effect of participation in GED programs on inmates' future wages, but rely only on matching on observables and not any exogenous variation in program participation. I recently began work using discontinuous assignment to rehabilitative services in Oregon prisons that I hope will provide estimates of the causal effect of prison activities on future recidivism. 
rehabilitative program completion is 12 percent higher) and have lower recidivism rates upon release.

In Appendix B, I show how these estimated parameters can be used to calibrate a recidivism function and then use this function to estimate the social benefit of incarceration. Even when I compare an optimal rule to a moderately biased parole board (one that assigns only 90 percent of the optimal prison term to each inmate), I find that the social costs incurred per prisoner (the cost of incarceration plus the cost of any future recidivism) increase by about $\$ 13,700$ (13 percent) when parole-board discretion is eliminated.

Although the empirical results and social-welfare calculations are obviously specific to the parole setting, the general framework used in the paper may prove useful in examining the decision between rules and discretion in other contexts. In the criminal justice arena, the discretionary power of judges and prosecutors has been called into question. ${ }^{42}$ If these agents are equally adept as parole boards at assessing how dangerous potential offenders truly are, then policymakers may wish to reexamine moves to limit discretion in these areas. Just as prisoners have less incentive to invest in their own rehabilitation in a rules-based regime, defendants may have less incentive to cooperate with the prosecution when judges and prosecutors cannot reward them with shorter sentences or generous plea arrangements. ${ }^{43}$

The question of whether a discretionary agent or a rule determines how long individuals are assigned to treatment programs appears to be receiving attention from policymakers outside of criminal justice as well. Public assistance used to be an entitlement for those meeting certain criteria, but with the creation of Temporary Assistance to Needy Families in 1996 how long

\footnotetext{
42 See Anderson, Kling and Smith (1999) on the limiting of judges' discretion and Wright (2005) on states' efforts to regulate prosecutors' decisions.

${ }^{43}$ Kuziemko (2006) shows that the bargaining power of prosecutors appears to affect plea-bargaining outcomes (defendants accept worse terms when prosecutors have more sentencing options at their disposal).
} 
recipients receive aid is now determined in part by the discretion of individual caseworkers (Lurie 1997). Conversely, teachers once had the final say as to who would be promoted to the next grade; now, standardized test scores play a key role, especially after the No Child Left Behind Act (Greene and Winters 2006). Future work might examine how these changes have affected the incentives clients face to make socially optimal investments. 


\section{Appendix A. A simple model of optimal prison release}

This appendix provides a simple model to illustrate more formally several claims made in Section 2: that the marginal social value of incarceration falls with time served and that parole boards should assign an inmate a shorter prison term when he exerts effort, thus creating a greater incentive for inmates to exert effort towards their own rehabilitation under a discretionary regime than under a rules-based regime. The appendix closes by exploring a contract-based model of parole.

\section{The basic framework}

Consider a set of inmates who appear identical at the time each is sentenced to $S$ years in prison. I assume that, through information revealed after an inmate has been sentenced, the parole board is able to differentiate between the inmates and observe their expected risk of recidivating. As in Section 2, the parole board seeks to allocate prison time to minimize the sum of incarceration costs plus future recidivism costs. ${ }^{44}$

An inmate's annual risk of recidivating, $R(r, e, t)$, depends on his initial recidivism risk, $r$, the effort he has put into his rehabilitation, $e$, and the time (in years) since his admission to prison, $t$. I do not directly model arrest and punishment in the post-release period, and instead assume that the inmate imposes social cost $\gamma$ if he recidivates and zero if he does not. ${ }^{45}$ Upon his admission, an inmate has $T$ years left in his criminal career, after which time he poses no danger to the community.

Under these assumptions, the total social cost associated with incarcerating an inmate for $t$ years (the incarceration cost plus the expected recidivism costs) is:

$$
I t+\gamma R(r, e, t)(T-t),
$$

where $I$ is the annual per-inmate cost of incarceration. For now, I assume that parole boards do not act strategically and thus take $e$ as given. Taking the derivative of (A1) with respect to $t$ yields the following first-order condition:

$$
I=\gamma\left[R\left(r, e, t^{*}\right)-R_{t}\left(r, e, t^{*}\right)\left(T-t^{*}\right)\right]
$$

\footnotetext{
${ }^{44}$ Since no consensus has yet emerged on the deterrence effect of longer sentences, or, more specifically, of truth-insentencing laws, I do not consider it in the model. Marvell and Moody (1996) find no deterrence effect of truth-insentencing laws using state panel data from the early 1970s to the early 1990s. Shepherd (2002) uses county panel data from 1984-1996 and finds that truth-in-sentencing laws have a large deterrence effect on violent crime. I find the Marvel and Moody study more convincing largely because of their inclusion of state-specific trends (I have confirmed their results in preliminary work extending the panel to 2003). As Sabol et al. (2002) argues, truth-insentencing reforms are usually passed during periods of heavy legislative activity on other tough-on-crime reforms, making state-specific trends essential in teasing out the specific effect of truth-in-sentencing laws on crime rates.

${ }^{45}$ A more realistic model would take into account the incapacitation costs of punishing the inmate in the postrelease period if he is reconvicted as well as the social costs associated with those who commit new crimes but are not caught. Choosing the optimal length of time served would involve solving a dynamic programming problem where the cost of recidivism incorporates future incarceration costs. Given that the goal of the model is not to find the optimal length of time served, but to compare the efficiency and incentives of two regimes that determine time served, I simplify the problem by assuming no future incarceration in the post-release period (or, equivalently, folding such costs into $\gamma$ ). I more carefully consider those who commit future crimes but are never caught in doing a back-of-the-envelope social-welfare calculation in Appendix B.
} 
subject to $t \leq S$, the original sentence. The left-hand side (the marginal cost of incarceration) is straight-forward: incarcerating an inmate for an additional year costs I dollars; the right-hand side (the marginal benefit) is more complicated.

\section{The marginal benefit curve}

The marginal benefit of an additional year of incarceration (the right-hand side of A2) has two components. First, incarceration prevents whatever crimes an inmate would have committed if free. This benefit is represented by the first term: the annual probability of recidivism, $R(r, e$, $t$ ), times the social $\cos t \gamma$. I call this term the "incapacitation benefit" of incarceration and it depends on the level of $R(r, e, t)$.

Second, incarceration might influence an inmate's future behavior if it permanently lowers his recidivism. In this case, the social benefit of an additional year of prison accrues over the rest of the inmate's criminal career. This "rehabilitation benefit" is captured by the second term: the change in the annual risk of recidivism due to time served, $R_{t}$, multiplied by the length of the inmate's remaining criminal career. Note that the rehabilitation benefit depends on $R_{t}$, the derivative of $R(r, e, t)$ with respect to time.

Recall that one of the key assumptions in Section 2 is that the marginal social benefit curve is downward sloping. Taking the derivative of the marginal social benefit curve with respect to time served yields:

$$
2 R_{t}-R_{t t}(T-t)>0
$$

If $R_{t}<0$ and $R_{t t}>0$, as suggested by the empirical results in Section 4 , then (A3) holds.

\section{Optimal time served in two regimes}

For each inmate, parole boards solve (A2) to determine the optimal $t^{*}$. (Note that the second-order condition to ensure a minimum is equivalent to A3.) Rearranging (A2) yields:

$$
t^{*}=\frac{\not R-I}{-\not R_{t}}+T
$$

The optimal term increases with remaining criminal career $T$, recidivism level $R$ and social cost of recidivism $\gamma$ and decreases with prison costs $I$. Note that the denominator is positive as $R_{\mathrm{t}}$ is assumed to be negative. The effect of $R_{\mathrm{t}}$ is ambiguous: as the magnitude of the slope increases, the rehabilitative effect of increases in $t$ rises but the incapacitation benefit falls.

Next, consider the optimization problem in a rules-based regime. The regime cannot condition on individual values of $r$ but only on its distribution:

$$
t^{R}=\underset{t \in[0, S]}{\arg \min }\left\{I t+\int_{r^{\min }}^{r^{\max }} \gamma R(r, e, t)(T-t) f(r) d r\right\} .
$$

Appendix B uses the formulae in (A4) and (A5) to simulate the social cost of crime under the two regimes.

\section{Effect of inmates' effort on the optimal time served in a parole regime}

What happens to the two components of the marginal benefit of incarceration when an inmate increases his effort? The incapacitation benefit falls, as effort decreases the probability of 
recidivism and the need to keep him in prison. However, the rehabilitation benefit rises if prison time and effort are complements in reducing recidivism.

The effect of these two competing forces on the parole board's decision can be illustrated mathematically by applying the implicit function theorem to (A2):

$$
\frac{\partial t^{*}}{\partial e}=\frac{R_{e}-R_{e t}(T-t)}{R_{t t}(T-t)-2 R_{t}}
$$

The denominator is positive by (A3). The numerator will be negative unless the interaction term is large and negative. In other words, unless the direct of effect of effort is outweighed by the interaction effect of time served and effort, then the optimal time served will fall when inmates increase effort.

In summary, for all recidivism functions $R(r, e, t)$ where $R_{e}<0, R_{t}<0, R_{t t}>0$ and $R_{e t}$ is bounded sufficiently from below and for any initial values of $e$ and $t^{*}$ such that the first-order condition $I=\gamma\left[R\left(r, e, t^{*}\right)-R_{t}\left(r, e, t^{*}\right)\left(T-t^{*}\right)\right]$ is satisfied, an increase in $e$ will decrease $t^{*}$, the optimal time served. That is, the optimization that parole boards perform incentivizes effort.

\section{Parole as a contracting problem}

Suppose parole boards assume effort is endogenous and set linear contracts of the following form:

$$
t=t_{0}+t_{1} r-t_{2} e
$$

I assume that effort as a function of $t_{2}$ has the following properties: $e^{\prime}>0, e^{\prime \prime}<0, e(0)=0$, and that $\lim _{t_{2} \rightarrow \infty} e\left(t_{2}\right)=1 .{ }^{46}$ As parole boards will review many future inmates, I assume they can credibly commit to any schedule they set.

Parole boards choose $t_{0}, t_{1}$, and $t_{2}$ so as to minimize the following expression for the total social cost, $C$ :

(A8) $\int_{r_{\min }}^{r_{\max }} I\left(t_{0}+t_{1} r-t_{2} e\left(t_{2}\right)\right)+\gamma R\left(r, e\left(t_{2}\right), t_{0}+t_{1} r-t_{2} e\left(t_{2}\right)\right)\left(T-t_{0}-t_{1} r+t_{2}\left(e\left(t_{2}\right)\right)\right) f(r) d r$,

subject to $t_{o} \geq 0, t_{1} \geq 0, t_{2} \geq 0, t_{o}+t_{1} \leq S, t_{o}-t_{2} \geq 0$. These conditions rule out negative time served or time served beyond the original sentence. Minimizing (A8) yields the following first-order conditions:

\footnotetext{
${ }^{46}$ I do not discuss the inmate's decision problem in great detail, as it is trivial to write down a model in which inmates exert more effort when effort shortens time served than when it does not. The specific properties of effort as a function of $t_{2}$ that I note above can be derived from a model in which inmates choose effort so as to maximize the sum of utility while in prison and utility after release, $-V(e) t\left(e\left(t_{2}\right)\right)+\bar{U}\left(T-t\left(e\left(t_{2}\right)\right)\right.$, where $V$ is flow disutility while in prison, and $\bar{U}$, a constant here for simplicity, is flow utility upon release. If one assumes convex disutility of effort and the usual Inada conditions $\left(V^{\prime}(0)=0, \lim _{e \rightarrow 1} V^{\prime}=\infty\right)$ then it can be shown that $e^{\prime}>0, e^{\prime \prime}<0, e(0)=0$, and $\lim _{t_{2} \rightarrow \infty} e\left(t_{2}\right)=1$.
} 


$$
\frac{\partial C}{\partial t_{0}}=0 \Rightarrow \int_{r_{\min }}^{r^{\max }}\left[I+\gamma R_{t}(T-t)-\gamma R\right] f(r) d r=0,
$$

$$
\frac{\partial C}{\partial t_{1}}=0 \Rightarrow \int_{r_{\min }}^{r^{\max }} r\left[I+\gamma R_{t}(T-t)-\gamma R\right] f(r) d r=0,
$$

and

(A11) $\frac{\partial C}{\partial t_{2}}=0 \Rightarrow \int_{r^{\min }}^{r^{\max }}\left[\mathcal{R}_{e} e^{\prime}(T-t)-I\left(e+t_{2} e^{\prime}\right)-\mathcal{R}_{t}\left(e+t_{2} e^{\prime}\right)(T-t)+\not R\left(e+t_{2} e^{\prime}\right)\right] f(r) d r=0$.

The first-order condition with respect to $t_{0}$ is very similar to the first-order condition when effort is taken as given (A2). In this case, the marginal cost of increasing time for the average prisoner (the annual cost of incarceration, $I$ ) is set equal to the marginal (incapacitation and rehabilitative) benefit. This similarity arises because $t_{0}$ does not have a direct effect on effort, so the optimization is similar to the case when parole boards take effort as given. The second first-order condition (A10) is similar to the first but now each term is weighted by $r$, as the effect of an increase in $t_{1}$ depends on the level of the initial recidivism risk, $r$.

The most complicated of these first-order conditions is (A11). The first two terms of the integrand are negative: they are the marginal decreases in cost represented by an increase in $t_{2}$ (which, recall, leads to a decrease in time served). The first term reflects how an increase in $t_{2}$ can increase the rehabilitation benefit of time served by incentivizing effort and the second term reflects the cost savings from decreasing time served. The last two terms are positive and represent the marginal increases in social cost related to recidivism. The third term demonstrates how an increase in $t_{2}$ can decrease the rehabilitative effect by decreasing time served. The final term represents the lost incapacitation value due to a decrease in time served.

Parole boards can solve for the optimal $t_{0}, t_{1}$ and $t_{2}$, but a rule-maker does not enjoy the same flexibility. I model the rule-maker's decision as minimizing (A8) with respect to $t_{0}$ when $t_{1}$ and $t_{2}$ are set to zero. Note that, by construction, effort is zero in a rules-based regime as $t_{2}$ is set to zero, so that the rule-setter in both the contracting setting and the exogenous-effort setting face the same optimization problem.

How does this contracting problem relate to the simpler model where effort is taken as given? First, the marginal benefit of incarceration as a function of time served is no longer a well-defined concept in the contract setting, as it will depend on how time served was changed (i.e., whether it was changed via a change in $t_{0}, t_{1}$ or $t_{2}$ ). Thus, Figure 1 no longer has a clear interpretation in this setting, though, as discussed above, one may think of it as illustrating an increase in the base time, $t_{0}$.

However, just as in the simpler model, an increase in effort reduces prison time. In the contracting setting, the board explicitly includes effort in its formula for time served. In the simpler model, this connection emerges because effort makes criminals less dangerous and the marginal value of incarceration falls, leading to an earlier release. In both cases, inmates have an added incentive to invest in their own rehabilitation in the parole regime relative to a rules-based regime. 


\section{Appendix B. Simulating per-prisoner social costs under different regimes}

This section attempts to compare in terms of estimated dollar values how well parole and rules-based regimes minimize the social costs associated with incarceration and future recidivism. Such an exercise requires many assumptions about functional form and parameter values. Whenever possible, I rely on administrative data, the empirical results from Sections 3-6, and findings from previous work to guide these assumptions.

\section{The recidivism function}

The results in Section 4 suggest that the effect of time served on recidivism is negative and diminishing and the results in Section 6 suggest that inmates' effort decreases recidivism. I therefore assume that $R(r, e, t)$ takes the following form:

which gives

and

$$
R(r, e, t)=(r-\alpha e) \delta^{t}
$$

$$
R_{t}=(r-\alpha e) \delta^{t} \ln (\delta)
$$

$$
R_{t t}=(r-\alpha e) \delta^{t}(\ln (\delta))^{2}
$$

Note that $R_{t}<0$ and $R_{t t}>0$ whenever $0<\delta<1$. I calibrate $\delta$ by dividing (B2) by (B1) and taking the average one-year recidivism rate from the data used in Table $3(0.086)$ and taking the average $R_{t}$ from the coefficient on time served in the last column of Table 3 (-0.00879). Converting from three-year recidivism rates as a function of months served to one-year rates as a function of years served yields $\delta=\exp (-0.0879 *(12 / 3) / 0.086)=0.66 .^{47}$

Following Appendix A, I assume that effort is a function of the incentive $t_{2}$ and has the following properties: $e^{\prime}>0, e^{\prime \prime}<0, e(0)=0$, and that $\lim _{t_{2} \rightarrow \infty} e\left(t_{2}\right)=1$. Here, I specifically assume that $e$ takes on the following functional form: $e=1-\left(\frac{1}{1+t_{2}}\right)$. Since effort has no natural units, it can be arbitrarily set in the case where effort is taken as given. When doing calculations in this case, I assume that effort takes on a value of 0.85 in a parole regime and zero otherwise. ${ }^{48}$

Section 6 suggested that a move from discretion to rules increases one-year recidivism rates by about 2 percentage points. ${ }^{49}$ Subtracting (B1) when $e=0.85$ from (B1) when $e=0$ implies that $\alpha=0.045$ :

\footnotetext{
${ }^{47}$ This calculation assumes that average time served is constant across the two regimes. See Section 6 for a discussion of why time served did not significantly increase in Georgia after the move from parole to rules.

${ }^{48}$ The functional form for recidivism given in (B1) requires knowledge of the level of effort $e$ as well as the value of the $\alpha$ parameter. From the empirical work, I only know the change in recidivism when effort if turned "on" (in the parole regime) relative to when it is turned "off" (in the rules regime). I therefore cannot separately identify $e$ and $\alpha$, giving me a free parameter in the model. When effort is taken as given, I can pick an arbitrary value when it is turned "on" and then solve for $\alpha$. To be able to compare between the cases when effort is taken as given and when effort is assumed to be endogenous, I pick values of $\alpha$ and $e$ so that the equilibrium effort in the contracting case is the same as the level of effort arbitrarily chosen in the effort-taken-as-given case. Such a situation is achieved when $\alpha=0.045$ and $e=0.085$. Finally, note that equating the two levels of effort could equivalently have been done by adding and then adjusting a parameter to the $e\left(t_{2}\right)$ function.

49 This number is based on a regression equivalent to that in Table 5 Col. (5) but with the one-year recidivism rate as the dependant variable. See notes to Table 5 .
} 


$$
0.014=r \delta^{t}-(r-\alpha e) \delta^{t}=\alpha e \delta^{t}=\alpha\left(\frac{2}{3}\right)\left(0.66^{2.4}\right) \Rightarrow \alpha \approx 0.045
$$

To estimate the distribution of $r$, the initial recidivism risk, I generate predicted recidivism by regressing the observations in Table 1 on the basic control variables used throughout the paper. Using my estimate for $\delta$ as well as each inmate's time served, I back-out each inmate's initial risk. The distribution of this measure appears roughly uniform between 0.1 and 0.7 .

To estimate $T$, the length of the average remaining criminal career, I examine a subsample of the inmate population who (1) meet my standard sampling criteria; and (2) were released before 1990 so that I can observe them for at least 15 years. I then subtract the year of an inmate's current conviction from the year of his final recorded conviction. While this variable is right-censored for inmates with very long criminal careers, there are very few values near the threshold so the extent of the censoring appears to be very limited. As the majority of inmates do not recidivate, their remaining criminal careers have zero length. The mean, conditional on recidivism, is 8.8 .

Finally, regardless of recidivism risk and effort, time served cannot exceed the original sentence. From Table 1, I assume $S$, the original sentence, is six years.

\section{Cost parameters}

A key parameter is the social cost incurred when an inmate recidivates. Let $O$ be the set of offenses recidivists commit and Cost the social cost associated with offense $j$. Let $S_{j}$ be $j$ 's share of all offenses recidivists commit, which I calculate from my data.

Assume that with probability $R\left(r_{i}, e_{i}, t_{i}\right)$ inmate $i$ recidivates and is caught; he thus imposes social cost $\operatorname{Cost}_{j}$ associated with the offense for which he was caught (which is observed in the data), as well as the social costs associated with (unobserved) offenses he committed but for which he was not caught. With probability $\left(1-R\left(r_{i}, e_{i}, t_{i}\right)\right)$, the inmate commits no future crimes, observed or unobserved. To account for the social cost of unobserved offenses, I weight each observed offense of type $j$ by the product of the inverses of the probability police are notified about offense $j$ and the probability that police make an arrest given a report of offense $j$ (known as the "clearance rate").

Under these assumptions:

$$
\gamma=\sum_{j \in O} S_{j}\left(\frac{1}{\text { Notify }_{j}}\right)\left(\frac{1}{\text { Clearance }_{j}}\right) \text { Cost }_{j} .
$$

Using values for Cost $_{j}$ from Cohen (1988) and Miller, Cohen, and Rossman (1993) and for Notify $_{j}$ and Clearance Clom $_{j}$, respectively, the National Crime Victimization Surveys and the FBI's Uniform Crime reports, I find that $\gamma \approx \$ 61,000$.

Finally, I look outside my data for an estimate of the annual cost of incarceration. I use a value of $\$ 24,000$ (dividing the values for total expenditures by total prisoners given in the BJS

\footnotetext{
${ }^{50}$ These probabilities are taken from the 2000 National Crime Victimization Survey and the 2000 Uniform Crime Reports, respectively.

51 This assumption most likely over-estimates the social cost of these crimes as the index crimes are considered the most serious offenses. However, as so much of the average cost of crime is being driven by the high social cost of murder, a wide range of values for the social cost of the non-index crimes yields a roughly similar value for the
} 
report State Prison Expenditures 2001). Freeman (1995) and DiIulio and Piehl (1995) report similar numbers.

In summary, I use the following parameter values for the social cost calculations: $\alpha=$ $0.08, I=\$ 24,000, \gamma=\$ 61,000, T=9$, and $\delta=0.66$. I assume that $r \sim \mathrm{U}[.1, .7]$.

\section{Calculating per-prisoner social cost under parole and rules-based regimes}

I first consider the case in which parole boards take effort as given, and report these results in the left-hand side of Table B1. The first row shows average time served, recidivism rates, and per-prisoner social cost when parole boards set prison terms optimally (i.e., solve equation (A2)). Inmates serve an average of 2.54 years and emerge with a one-year recidivism rate of 0.109 . These results match the data fairly well. The social cost imposed by the average prisoner is $\$ 102,997$, of which over half $(\$ 60,960)$ arises from incarceration costs and the remainder from future recidivism costs.

Because parole boards are often considered too lenient, the second row shows the relevant outcomes when parole boards solve for optimal time served but then scale the value by 0.9. Similarly, the third row considers the case when they halve the optimal time. A 10 percent downward bias increases social costs by less than 1 percent, while a 50 percent bias increases costs by 16 percent.

The fourth row displays the simulated outcomes corresponding to the optimal rule. I assume first that behavior does not change, so the change in social cost between this row and the first reflects only the loss due to the inability to assign high-risk inmates longer terms, not any loss due to moral hazard. Even without the loss from moral hazard, social cost increases by 7 percent relative to optimal parole.

In the final row, I assume that effort now falls to zero. The optimal time served increases in response to the increased incapacitation benefit of imprisonment, increasing total incarceration costs. However, despite longer sentences, inmates are still more dangerous when they leave, as they have exerted no effort towards rehabilitation while in prison, increasing recidivism costs. The total increase in costs relative to optimal parole is 11 percent.

I now consider the case in which parole boards view effort as endogenous. Results are reported in the second half of Table $\mathrm{C} 1$ (and I include the optimal linear contract that generates the results reported in the first row in the footnotes). The same trends emerge. Only when parole boards are significantly biased are rules and discretion comparable. Otherwise, parole appears to provide significant savings.

In the case of Georgia, the most relevant comparison appears to be between rows two and five. There was a small increase in time served after the state's move from parole to rules, suggesting some leniency on the part of parole boards; there was also a significant decrease in effort and increase in recidivism after the reform. In the case when parole boards view effort as given (endogenous), the move from discretion to rules increases the average per-prisoner social cost by about $\$ 10,549(\$ 7084)$ or 10 (7) percent.

average cost of crime. For example, assigning a social cost of zero to the non-index crimes yields an average social cost of crime of $\$ 52,745$.

52 The median recidivating inmate in the Georgia data committed a non-index crime, so his social cost would be $\$ 15,400$, or whatever value was assigned to non-index recidivists. 
Table B1. Total social cost per prisoner under different regimes

\begin{tabular}{l|ccc|ccc}
\hline & \multicolumn{3}{|c|}{ Exogenous effort } & \multicolumn{3}{c}{ Endogenous effort } \\
\hline Regime & $\begin{array}{c}\text { Time } \\
\text { served }\end{array}$ & Recid. rate & Social cost & $\begin{array}{c}\text { Time } \\
\text { served }\end{array}$ & Recid rate & Social cost \\
& 2.54 & 0.11 & 103,000 & 2.60 & 0.11 & 105,900 \\
Optimal parole & 2.30 & 0.12 & 103,500 & 2.34 & 0.13 & 107,000 \\
Parole, 10\% bias & 1.27 & 0.19 & 120,000 & 1.30 & 0.20 & 125,800 \\
Parole, 50\% bias & 2.85 & 0.11 & 109,900 & 2.85 & 0.11 & 109,900 \\
Opt. Rule, no behav. response & 3.04 & 0.12 & 114,100 & 3.04 & 0.12 & 114,100 \\
Opt. Rule, behav. response & 2.39 & 0.12 & -- & 2.39 & 0.119 & -- \\
Actual values from data & \multicolumn{2}{|c|}{} & & & &
\end{tabular}

Notes: Values in the first five rows are from simulations assuming that recidivism is defined as $R(r, e, t)=(r-\alpha e) \delta^{t}$, that initial risk $\mathrm{r}$ is distributed as U[.1,.7] and that parameter values are as follows: length of the remaining criminal career $T=9$, social cost of recidivism $\gamma=\$ 61,600$, annual cost of incarceration $I=\$ 24,000$, decay parameter $\delta=0.66$, and the effort parameter $\alpha=0.045$. When effort is taken as given, I assume that inmates set $e=0.85$ in the parole regime and zero in the rules-based regime. See Appendix B for a derivation of these parameter values. The optimal contract in the case where effort is taken as endogenous is given by $t_{0}=1.96, t_{1}=4.04$ and $t_{2}=1.60$. The values in the last row are taken from the same sample of prisoners used in Table 1.

\section{Appendix C. The Georgia Grid}

Table C1. The Georgia grid recommendations (in months)

\begin{tabular}{c|ccc}
\hline & & Points & \\
\hline Crime severity level & Excellent (14-20) & Average (9-18) & Poor(1-8) \\
\hline 1 & 10 & 16 & 22 \\
2 & 12 & 18 & 24 \\
3 & 14 & 20 & 26 \\
4 & 16 & 22 & 28 \\
5 & 34 & 40 & 52 \\
6 & 52 & 62 & 78 \\
7 & 72 & 84 & 102 \\
\hline
\end{tabular}




\section{Sources}

Abadinsky, Howard. 2003. Probation and Parole: Theory and Practice. Upper Saddle River, NJ: Prentice Hall.

Angrist, Joshua D., "Treatment Effect Heterogeneity in Theory and Practice, " Economic Journal, Vol. 114: C52-C83

Austin, James, and Robert Lawson. 1998. Assessment of California Parole Violations and Recommended Intermediate Programs and Policies. San Francisco: National Council on Crime and Delinquincy.

Bayer, Patrick J., Pintoff, Randi and Pozen, David E. 2004 "Building Criminal Capital behind Bars: Peer Effects in Juvenile Corrections" (March 2004). Yale University Economic Growth Center Discussion Paper No. 864.

Becker, Gary. 1968. "Crime and Punishment: An Economic Approach,” Journal of Political Economy Vol. 76, No. 2: 169-217.

Chen, Keith and Shapiro. 2004. Jesse M., "Does Prison Harden Inmates? A Discontinuity-based Approach," Cowles Foundation Discussion Paper No. 1450.

Cohen, Mark. 1988. "Pain, Suffering, and Jury Awards: A Study of the Cost of Crime to Victims," Law and Society Review 22: 537-555.

Cullen, Frances T. "Rehabilitation and Treatment Programs.” In James Q. Wilson and Joan Petersilisa, eds., Crime: Public Policy for Crime Control. Oakland, California: Institute for Contemporary Studies: 253-290.

Dilulio, John and Anne Piehl. 1991. "Does Prison Pay? The Stormy National Debate over the Cost-Effectiveness of Imprisonment," The Brookings Review (Fall 1991): 28-35.

Federal Bureau of Investigation. 2001. Crime in the United Sates, 2000. Washington, D.C.: U.S. G.P.O.

Freeman, Richard. 1996. "Why Do So Many Young American Men Commit Crimes and What Might We Do About It?" Journal of Economic Perspectives, Vol. 10, No. 1 (Winter): 25-42.

Greene, Jay and Marcus Winters. 2006. "Getting Ahead by Staying Behind," Education Next: 2006 (Spring): 65-69.

Hirschi, Travis and Michael Gottfredson. 1983. "Age and the Explanation of Crime," The American Journal of Sociology. Vol. 89, No. 3: 552-584.

Holmes, Steven. 1999. "Inmate Violent on Rise as Federal Prisons Change," New York Times, February 9, 1995: A1. 
Katz, Lawrence, Steven D. Levitt and Ellen Shustorovich. 2003. "Prison Conditions, Capital Punishment, and Deterrence," American Law and Economic Review, Vol. 5 No.2: 318-343.

Kessler, Daniel and Steven Levitt. 1999. "Using Sentence Enhancements to Distinguish Between Deterrence and Incapacitation," Journal of Law and Economics, Vol. 42, No.1: 343-63.

King, Ryan S. and Marc Mauer. 2002. State Sentencing and Corrections Policy in an Era of Fiscal Restraint. Washington DC: The Sentencing Project.

Kling, Jeffrey. 2006a. "Incarceration Length, Employment, and Earnings," The American Economic Review, Vol. 96, No. 3. (June): 863-876.

Kling, Jeffrey. 2006b. "Incarceration Length, Employment, and Earnings," NBER Working Paper No. W12003.

Kuziemko, Ilyana and Steven Levitt. 2004. "An Empirical Analysis of Imprisoning Drug Offenders," Journal of Public Economics. Vol. 88 (August): 2043-2066.

Kuziemko, Ilyana. 2006. "Does the Threat of the Death Penalty Affect Plea Bargains in Murder Cases? Evidence from New York's 1995 Reinstatement of Capital Punishment," American Law and Economic Review, Vol. 8, No. 1: 116-142.

Lee, David S. and Justin McCrary. 2005. "Crime, Punishment, and Myopia" NBER Working Paper No. W11491.

Levitt, Steven. 1996. "The Effect of Prison Population Size on Crime Rates: Evidence from Prison Overcrowding Litigation," Quarterly Journal of Economics, Vol. 111, No. 2: 319-51.

Levitt, Steven. 2004. “Deterrence.” In James Q. Wilson and Joan Petersilisa, eds., Crime: Public Policy for Crime Control. Oakland, Calif.: Institute for Contemporary Studies: 435-50

Lurie, Irene. 1997. "Temporary Assistance for Needy Families: A Green Light for the States," Publius, Vol. 27, No. 2: 73-87

Martinson, Robert. 1974. "What Works?-Questions and Answers About Prison Reform," The Public Interest, 35 (Spring): 22-54.

Marvell, Thomas and Carlisle Moody. 1996. "Determinate Sentencing and Abolishing Parole: The Long-Term Impacts on Prisons and Crime," Criminology, Vol. 34, No. 1: 107-128.

Miller, Ted, Mark Cohen and Shelli Rossman. 1993. "Victim Costs of Violent Crime and Resulting Injuries," Health Affairs," 22: 186-197.

Petersilia, Joan. 1999. "Parole and Prisoner Reentry in the United States," Crime and Justice, 26: 479-529. 
Petersilia, Joan. 2006. "Understanding California Corrections," California Policy Research Center Research Report.

Robitscher, Jonas. 1980. The Power of Psychiatry. Boston: Houghton Mifflin.

Sabol, William J., Katherine Rosich,Kamala Kane, David Kirk, Glenn Dubin.. 2002. “The Influences of Truth-in-Sentencing Reforms on Changes in States' Sentencing Practices and Prison Populations," Urban Institute Research Report.

Schmertmann, Carl P., Adansi A. Amankwaa, Robert D. Long. 1998. "Three Strikes and You're Out: Demographic Analysis of Mandatory Prison Sentencing," Demography, Vol. 35, No. 4 (November): 445-463.

Shepherd, Joanna. 2002. "Police, Prosecutors, Criminals, and Determinate Sentencing: The Truth About Truth-in-Sentencing Laws," Journal of Law and Economics 45 (October): 509-533.

Taylor-Thompson, Kim. 2000. "Winning the War on Drugs: A 'Second Chance' for Nonviolent Drug Offenders, Harvard Law Review, 113 : 1485-1502.

Tyler, John H. and Kling, Jeffrey R. 2006. "Prison-Based Education and Re-Entry into the Mainstream Labor Market," NBER Working Paper No. W12114

U.S. Dept. of Justice, Bureau of Justice Statistics. Various years. Correctional Populations in the United States, [various years]. Washington, DC: U.S. Dept. of Justice.

U.S. Dept. of Justice, Bureau of Justice Statistics. Various years. Probation and Parole in the United States, [various years]. Washington, DC: U.S. Dept. of Justice.

U.S. Dept. of Justice, Bureau of Justice Statistics. 1998. State Court Sentencing of Convicted Felons, 1997. Washington, DC: U.S. Dept. of Justice.

U.S. Dept. of Justice, Bureau of Justice Statistics. 2001. National Crime Victimization Survey, 2000. Washington, DC: U.S. Dept. of Justice.

U.S. Census Bureau. Various years. Statistical Abstract of the United States [various years]. Washington, DC: U.S. GPO.

Van Voorhis, Patricia, Sandra Browning, Marilyn Simon, and Jill Gordon. 1997. "The Meaning of Punishment: Inmates' Orientation to the Prison Experience," The Prison Journal 77: 135-67.

Western, Bruce. 2006. Punishment and Inequality in America. New York: Russell Sage Foundation.

Wright, Ronald F. 2005. "Sentencing Commissions as Provocateurs of Prosecutor SelfRegulation," Columbia Law Review 105: 1010-1047. 
Figure 1. Inmates released from prison by type of release

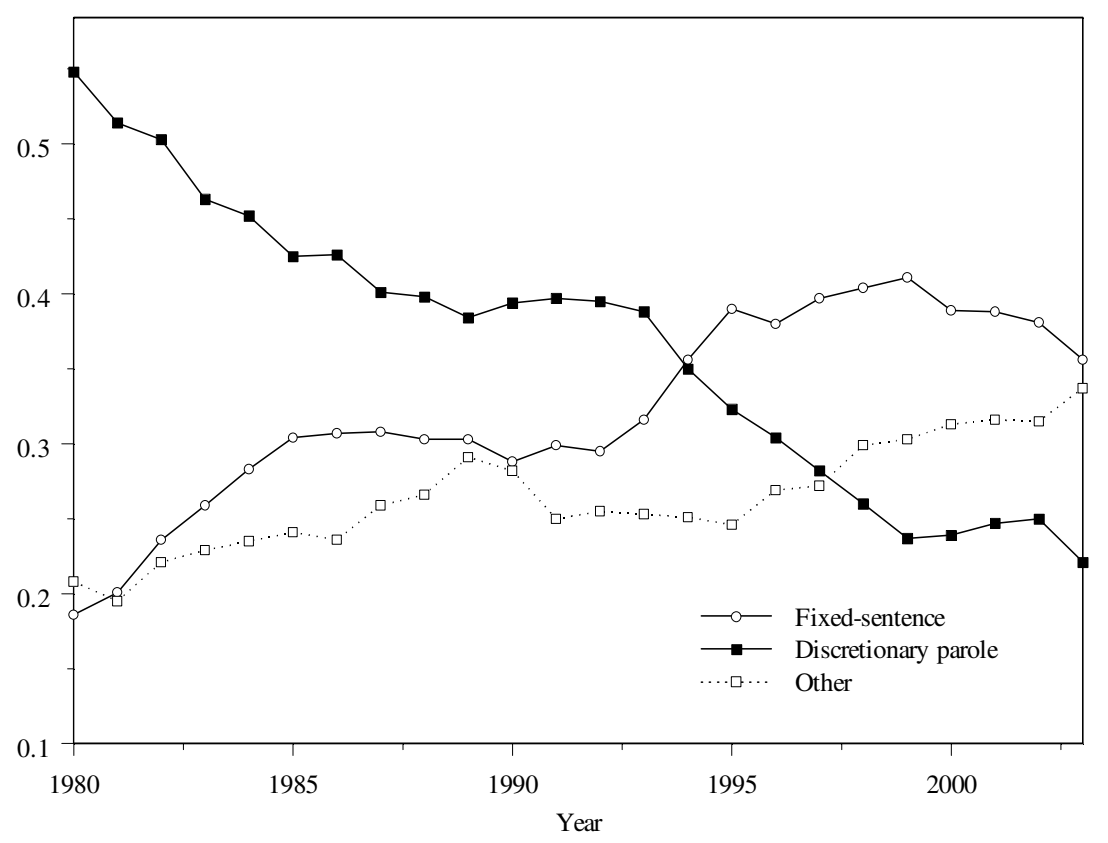

Notes: Taken directly from the Bureau of Justice Statistics publication "Probation and Parole in the United States, 2004." Because consistent data on the type of release are not readily available before 1980, Figure 2 actually understates the stark shift away from parole since a few years earlier, before California and Illinois abolished parole, the discretionary share was much larger. The "other" category includes those who served until the expiration of their sentence (whether due to a parole-board decision or a statutory requirement), those released due to overcrowding orders, those transferred to other states, those whose sentences were commuted or overturned, those who died while incarcerated, and those who escaped. 
Figures 2 a-c. Release dates under discretion and fixed sentences

(a)

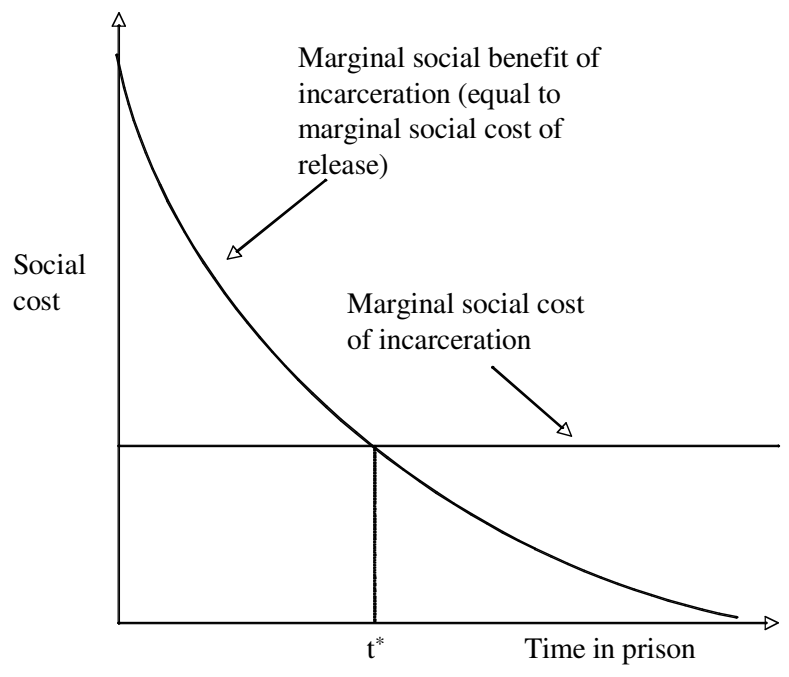

(b)

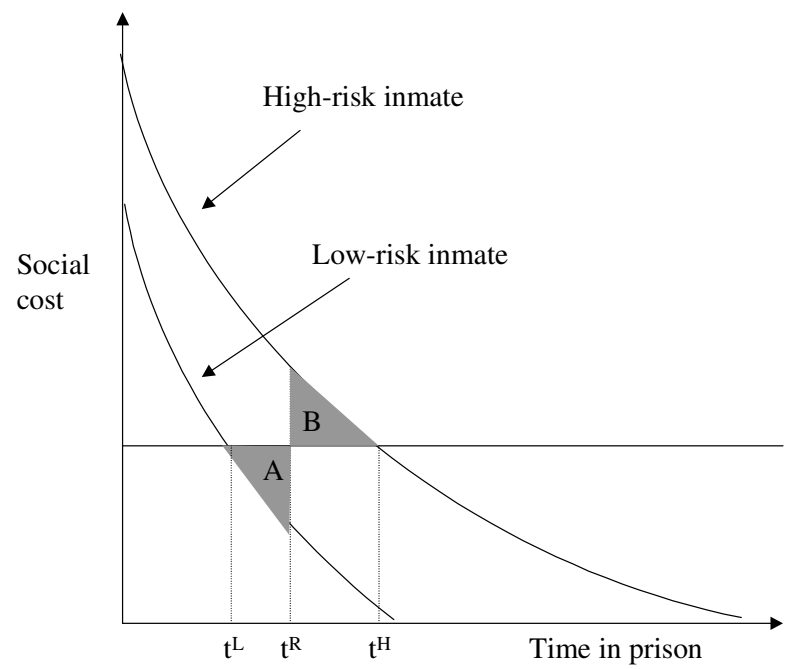

(c)

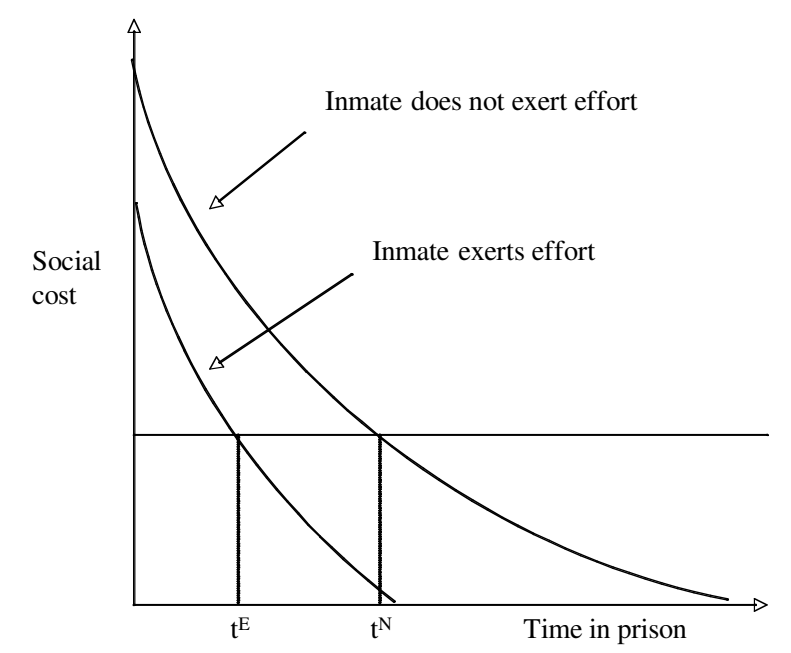


Figure 4a. Time served across point designations from the Georgia grid

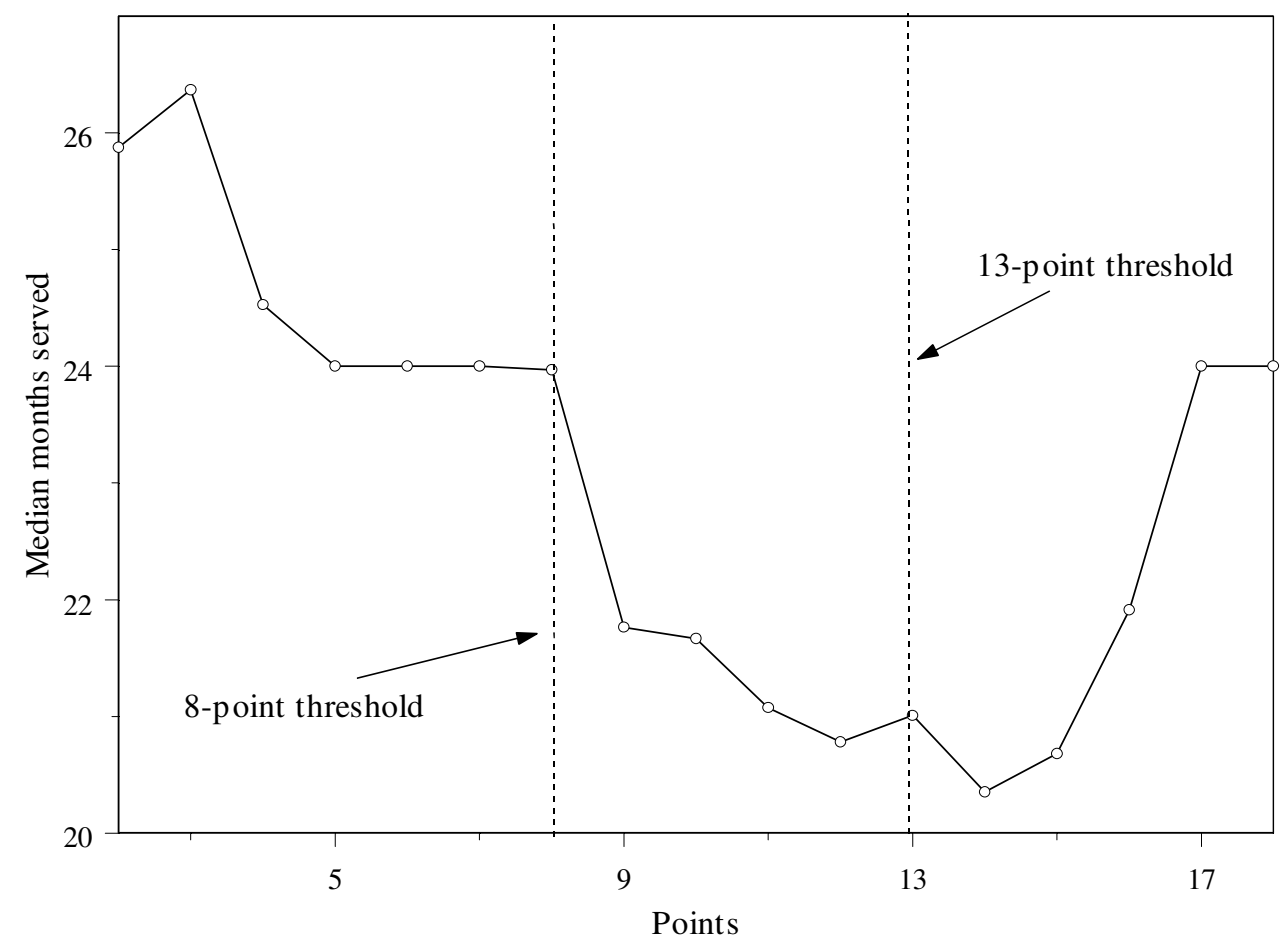

Figure 4b. Prior incarcerations across point designations from the Georgia grid

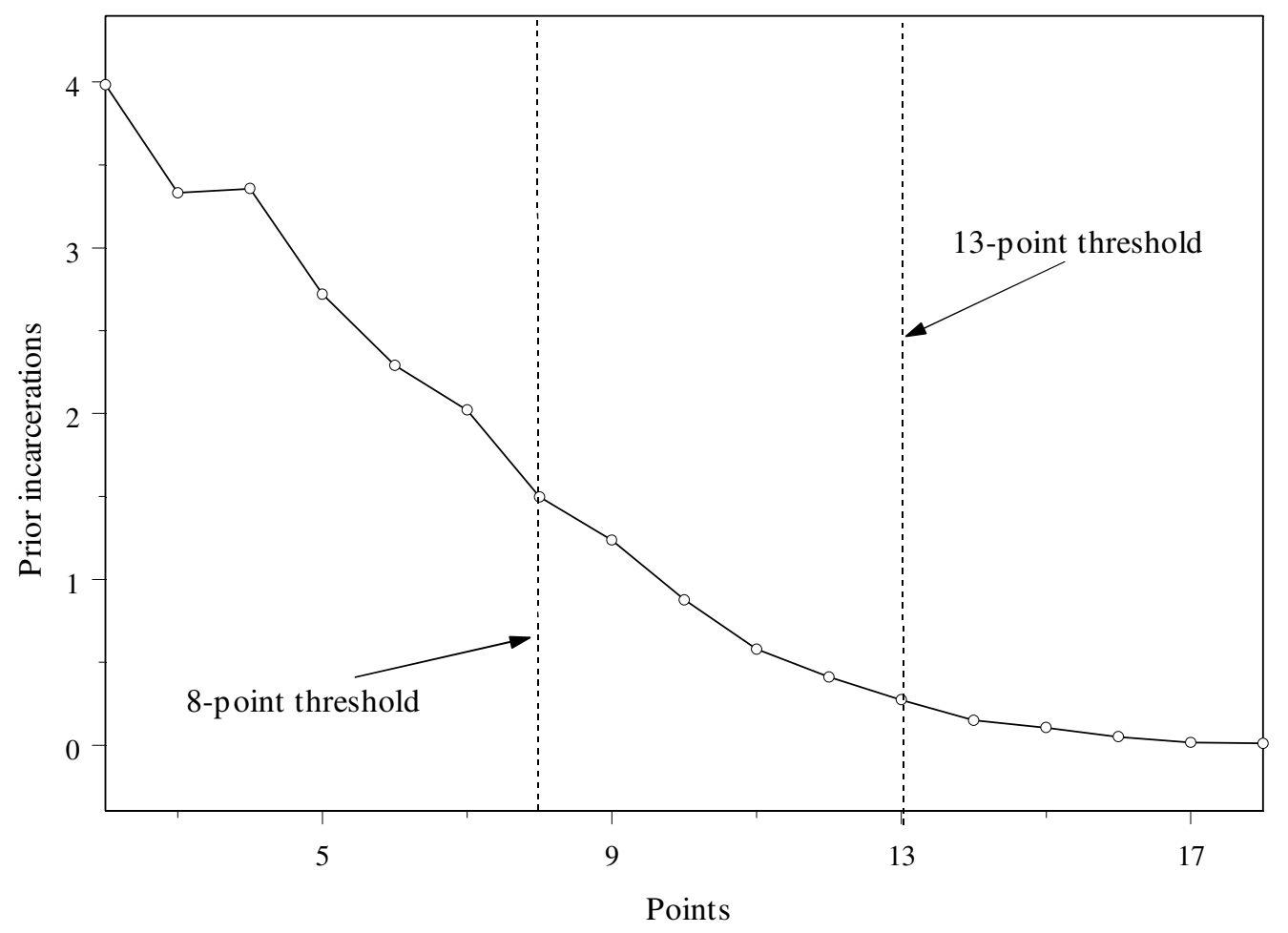


Figure 5. Recidivism rates by point designation from the Georgia grid

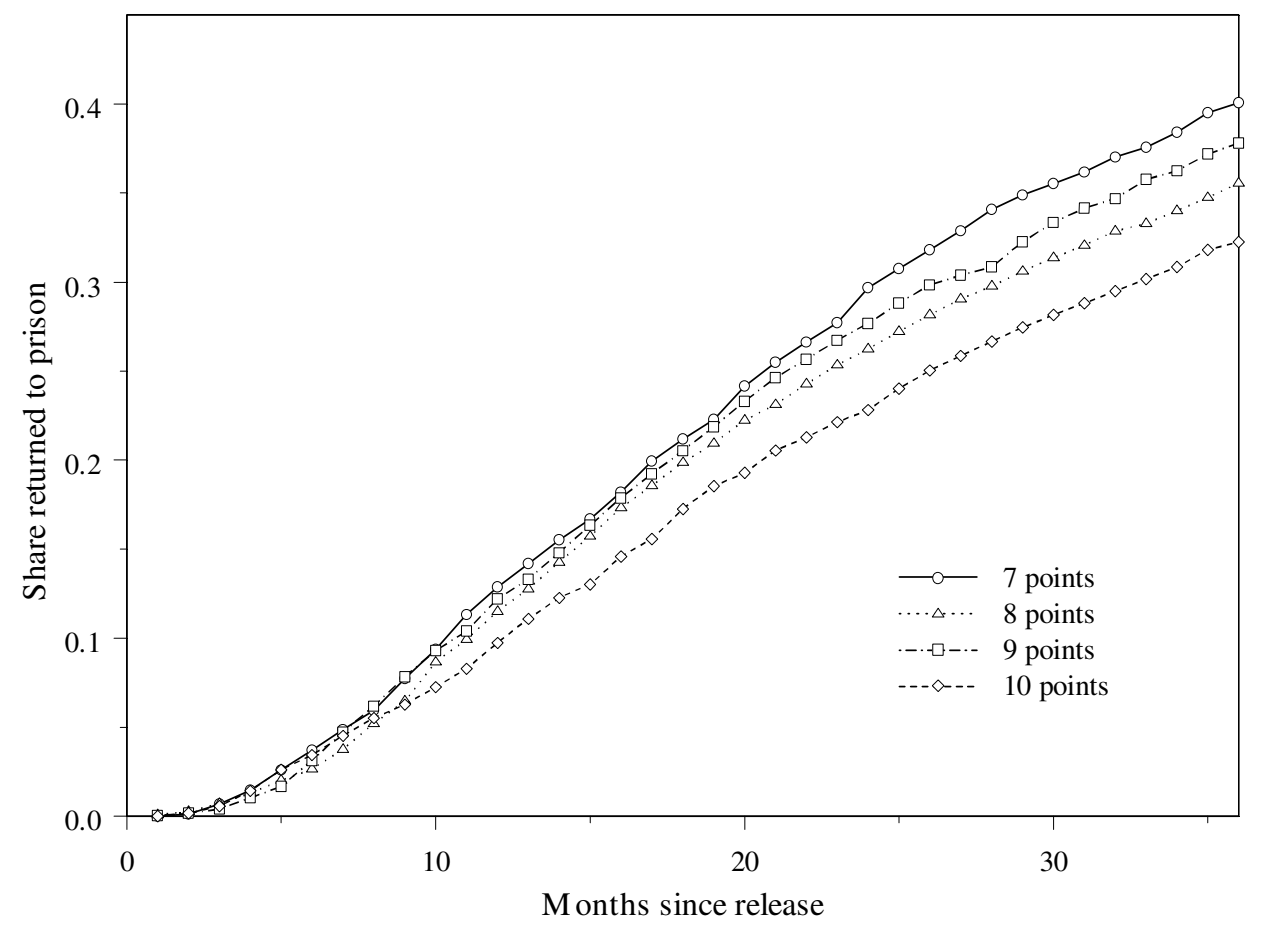

Figure 6 . The ability of observable variables to predict recidivism

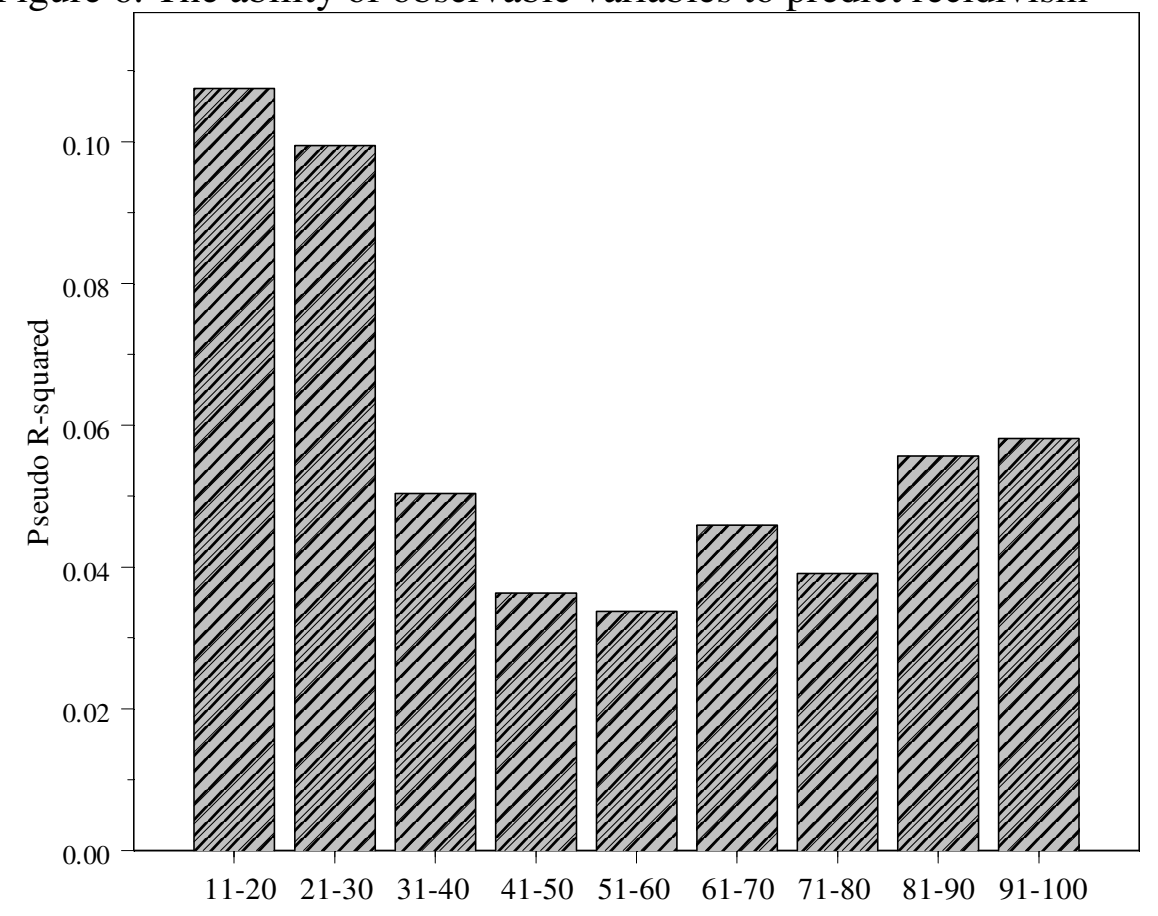

Parole-board recommendation as a percentage of original sentence 
Figure 7a: Effect of $90 \%$ reform on percent of sentence served (median inmate)

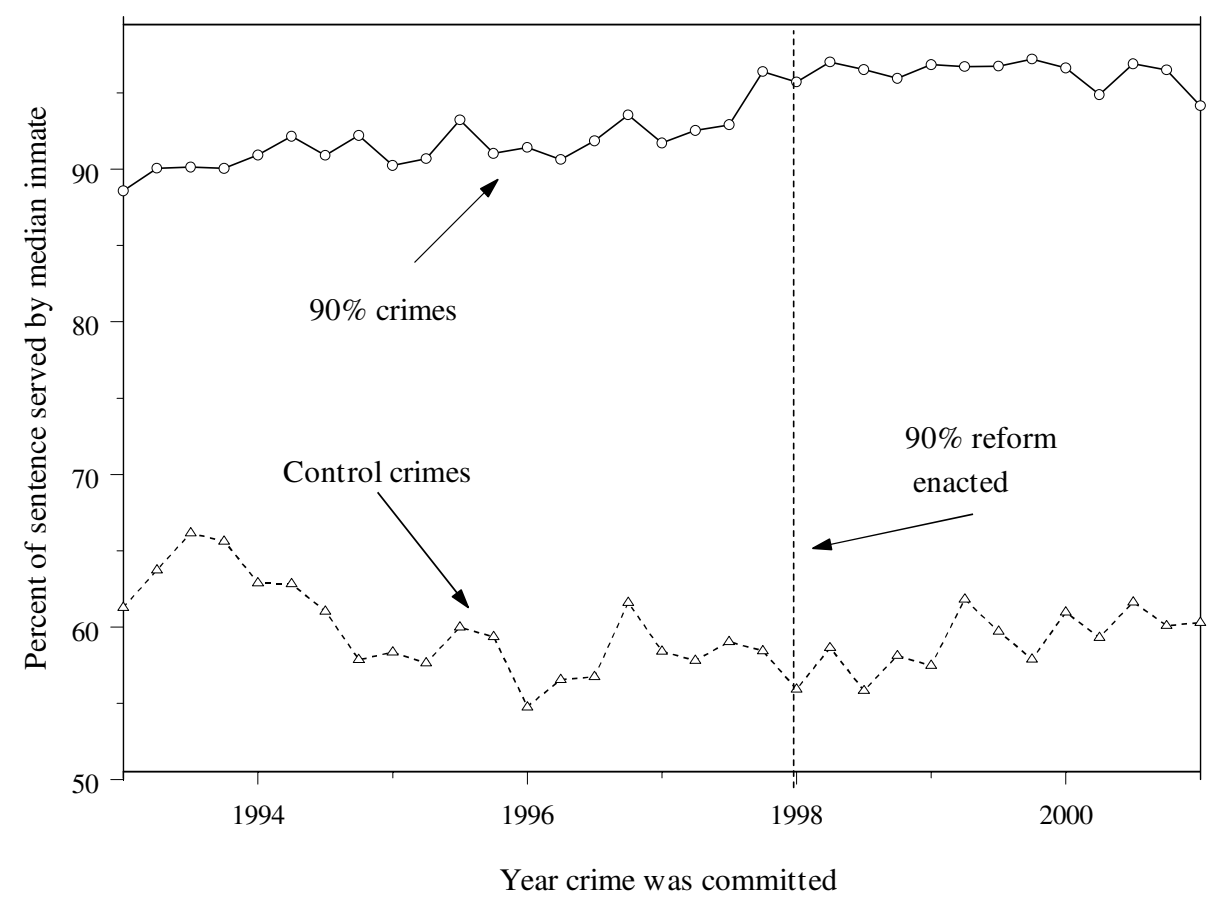

Figure 7b: Effect of $90 \%$ reform on percent of sentence served (inmate at $10^{\text {th }}$ percentile)

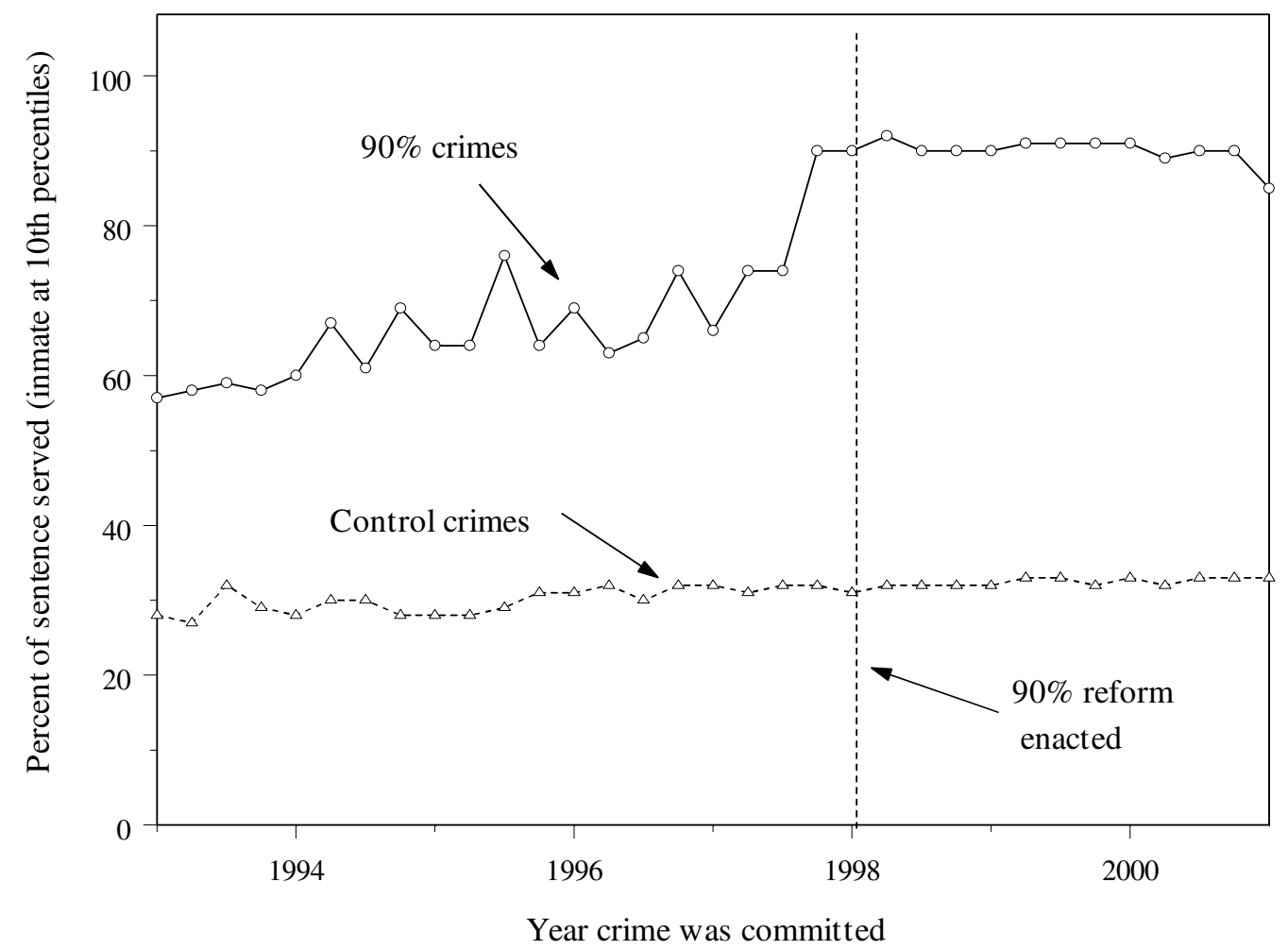


Figure 7c. Effect of $90 \%$ reform on original sentence length

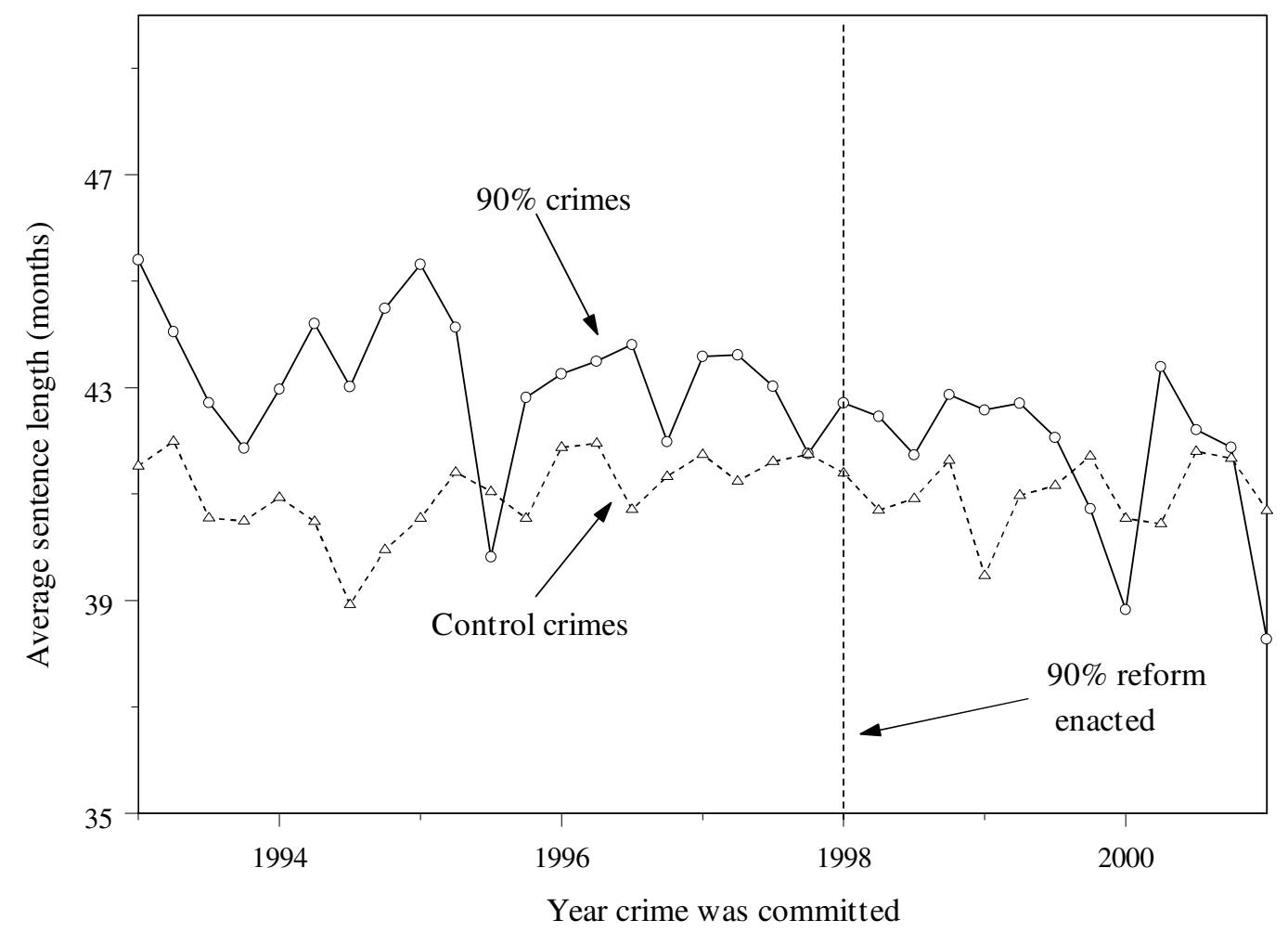

Figure 7d. Effect of $90 \%$ reform on time served

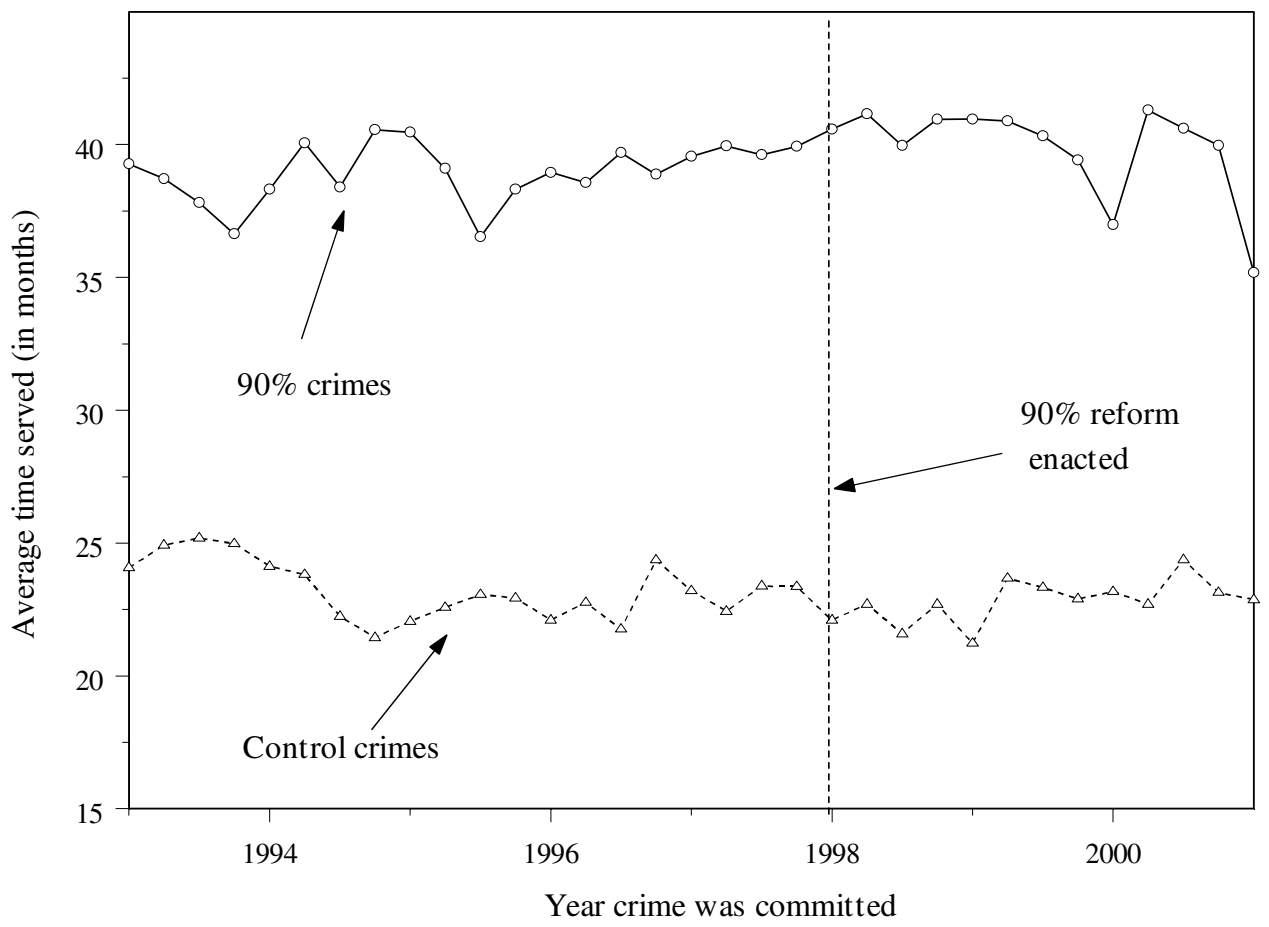


Figure 8. Effect of $90 \%$ reform on disciplinary infractions

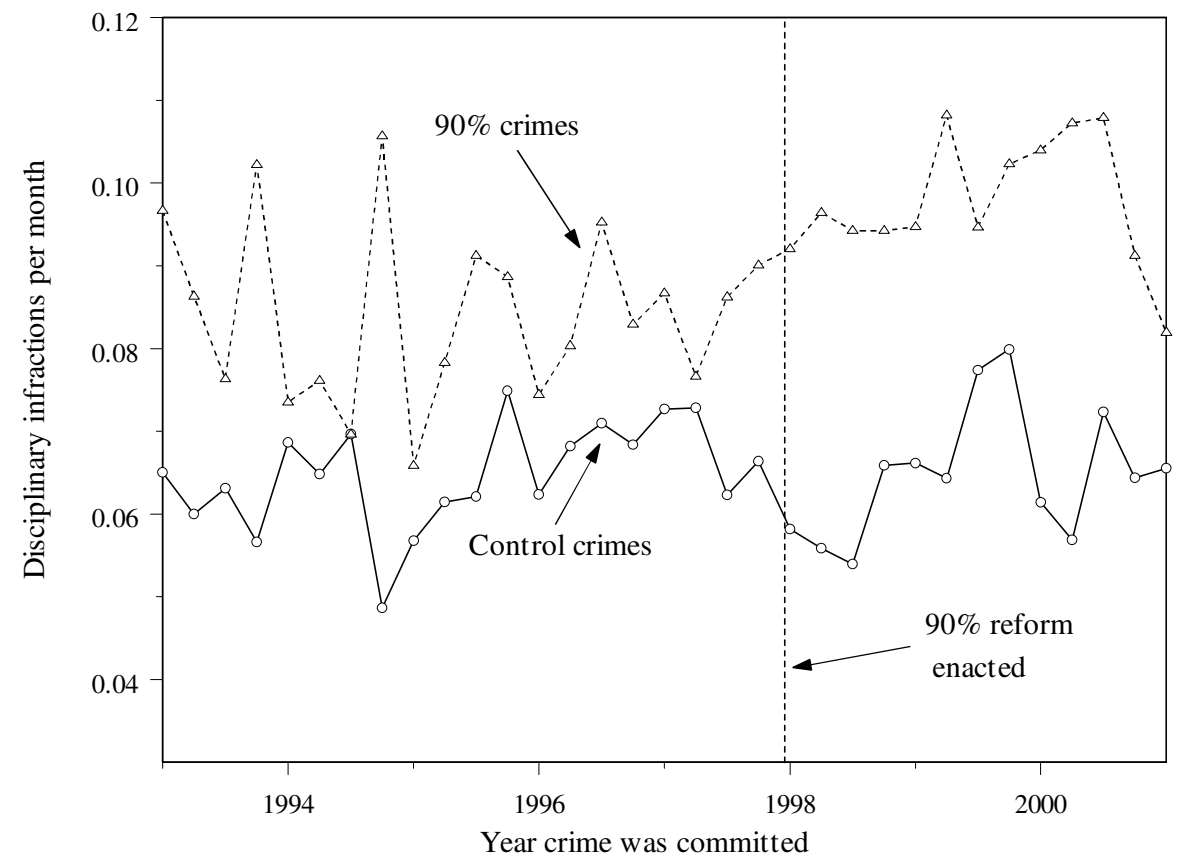

Figure 9: Effect of 90\% reform on completion of prison courses

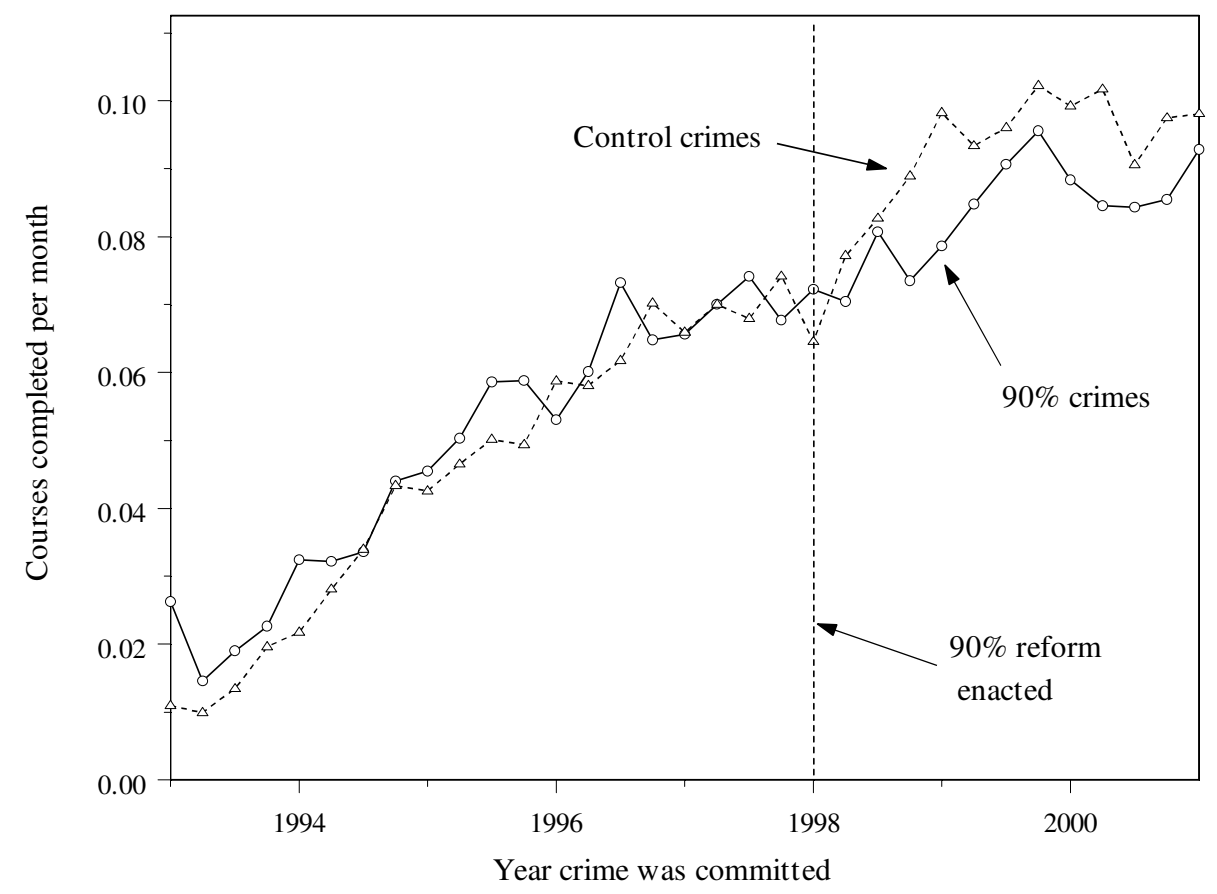

Notes: Georgia began collecting information on program enrollment and completion in 1994, but several more years passed before administrators in all facilities were reporting such information regularly for each inmate. Thus, the strong upward trend shown in Figure 8 is driven mostly by improvements in reporting rather than increases in participation. 
Figure 10: Effect of $90 \%$ reform on recidivism

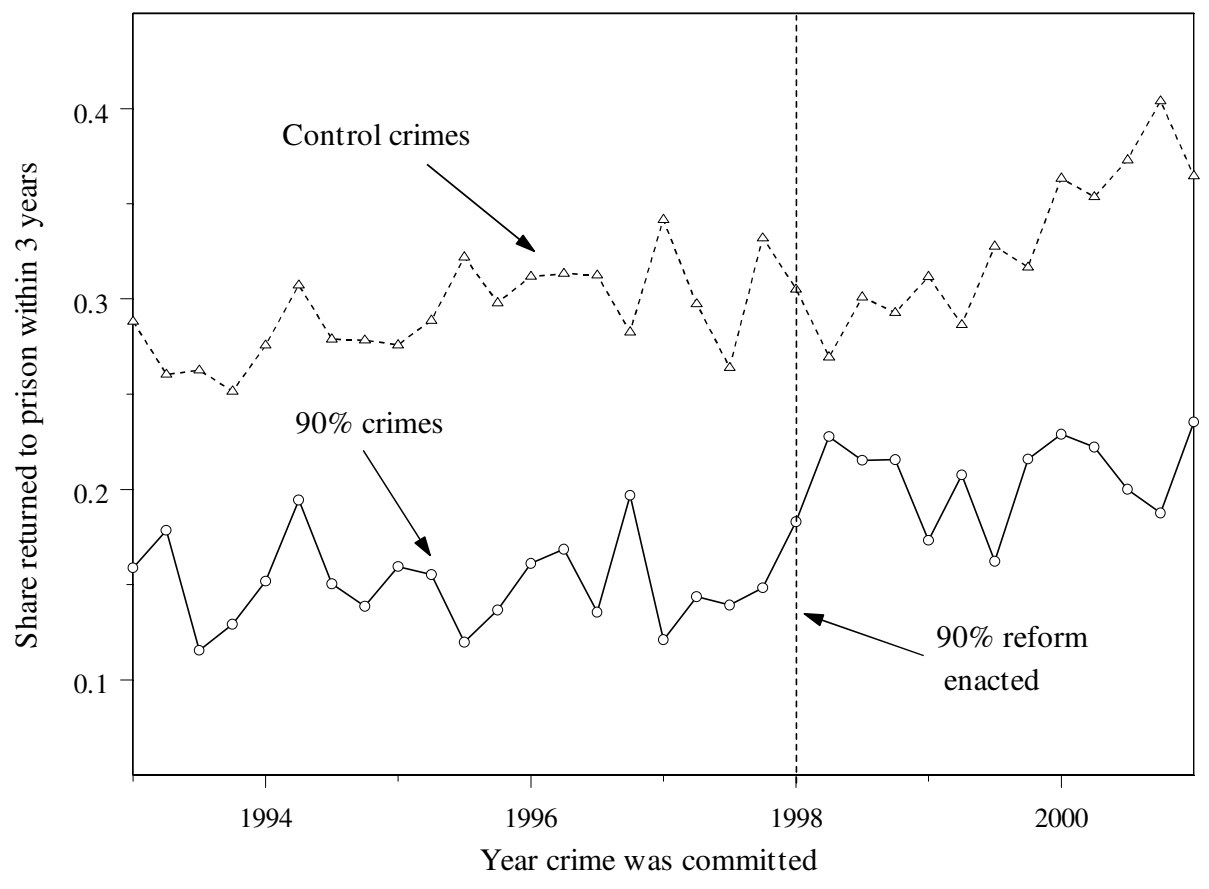


Table 1. Summary statistics on inmates, Georgia Department of Corrections

\begin{tabular}{l|cc}
\hline Variable & Mean & Standard deviation \\
\hline Returned to prison within 36 months & 0.296876 & 0.4568843 \\
Time served, in months & 28.66479 & 19.80527 \\
Original sentence, in months & 72.20594 & 63.56553 \\
Black & 0.6210248 & 0.485135 \\
Male & 0.9093542 & 0.2871067 \\
Age at release & 33.44245 & 9.484807 \\
Prior felony convictions & 1.423163 & 1.682511 \\
\hline
\end{tabular}

Notes: These data are from the administrative files of the Georgia Department of Corrections. All observations correspond to inmates who were admitted after 1980 and released before 2003, have non-missing values for all of the above variables, were given sentences between 6 and 120 months, and were admitted to prison directly from court. Limiting the sample according to these conditions yields 78,393 observations. 
Table 2. The effect of time served on recidivism, using the 1981 mass release

\begin{tabular}{|c|c|c|c|c|c|c|}
\hline & $\begin{array}{l}\text { Linear } \\
\text { prob. } \\
(1)\end{array}$ & $\begin{array}{c}\text { Linear } \\
\text { prob. } \\
(2)\end{array}$ & $\begin{array}{c}\text { Linear } \\
\text { prob. } \\
(3)\end{array}$ & $\begin{array}{c}\text { Linear } \\
\text { prob. } \\
(4)\end{array}$ & $\begin{array}{c}\text { Linear } \\
\text { prob. } \\
(5)\end{array}$ & $\begin{array}{c}\text { Cox } \\
\text { hazard } \\
(6) \\
\end{array}$ \\
\hline Time served & $\begin{array}{l}0.00345 \\
(0.0021)\end{array}$ & $\begin{array}{l}-0.0101 \\
(0.0062)\end{array}$ & $\begin{array}{l}-0.0257 \\
(0.0126)\end{array}$ & $\begin{array}{l}-0.0298 \\
(0.0128)\end{array}$ & $\begin{array}{l}-0.0302 \\
(0.0132)\end{array}$ & $\begin{array}{c}0.9393 \\
(0.0362)\end{array}$ \\
\hline $\begin{array}{l}\text { Original parole } \\
\text { recommendation }\end{array}$ & & & $\begin{array}{c}0.0201 \\
(0.0142)\end{array}$ & $\begin{array}{c}0.0272 \\
(0.0151)\end{array}$ & $\begin{array}{c}0.0300 \\
(0.0155)\end{array}$ & $\begin{array}{c}1.0463 \\
(0.0466)\end{array}$ \\
\hline Black & $\begin{array}{c}0.0521 \\
(0.0411)\end{array}$ & $\begin{array}{c}0.0535 \\
(0.0413)\end{array}$ & $\begin{array}{c}0.0529 \\
(0.0412)\end{array}$ & $\begin{array}{c}0.0646 \\
(0.0419)\end{array}$ & $\begin{array}{c}0.0671 \\
(0.0431)\end{array}$ & $\begin{array}{c}1.3794 \\
(0.1792)\end{array}$ \\
\hline Male & $\begin{array}{c}0.0355 \\
(0.0798)\end{array}$ & $\begin{array}{c}0.0243 \\
(0.0797)\end{array}$ & $\begin{array}{c}0.0345 \\
(0.0800)\end{array}$ & $\begin{array}{c}0.0416 \\
(0.0803)\end{array}$ & $\begin{array}{c}0.0516 \\
(0.0859)\end{array}$ & $\begin{array}{c}1.1884 \\
(0.3171)\end{array}$ \\
\hline Age at release & $\begin{array}{l}-0.0097 \\
(0.0025)\end{array}$ & $\begin{array}{l}-0.0094 \\
(0.0025)\end{array}$ & $\begin{array}{l}-0.0090 \\
(0.0025)\end{array}$ & $\begin{array}{l}-0.0085 \\
(0.0025)\end{array}$ & $\begin{array}{l}-0.0074 \\
(0.0027)\end{array}$ & $\begin{array}{c}0.9671 \\
(0.0093)\end{array}$ \\
\hline Prior felonies & $\begin{array}{c}0.0928 \\
(0.0238)\end{array}$ & $\begin{array}{c}0.0913 \\
(0.0240)\end{array}$ & $\begin{array}{c}0.0933 \\
(0.0240)\end{array}$ & $\begin{array}{c}0.0934 \\
(0.0243)\end{array}$ & $\begin{array}{c}0.0927 \\
(0.0250)\end{array}$ & $\begin{array}{r}1.4854 \\
(0.1002)\end{array}$ \\
\hline $\begin{array}{l}\text { Sentence-length fixed } \\
\text { effects? }\end{array}$ & No. & Yes. & Yes. & Yes. & Yes. & Yes. \\
\hline Offense fixed effects? & No. & No. & No. & No. & Yes. & Yes. \\
\hline Outliers excluded? & No. & No. & No. & Yes. & Yes. & Yes. \\
\hline Observations & 543 & 543 & 543 & 530 & 530 & 542 \\
\hline R-squared & 0.0641 & 0.0733 & 0.0750 & 0.0722 & 0.0961 & -- \\
\hline
\end{tabular}

Notes: The dependent variable is a dummy variable equal to one if the inmate returned to prison within three years of his release and zero otherwise. Cols. (1) - (5) use linear probability models; the coefficients should therefore be interpreted as changes in probability. Col. (6) uses a Cox proportional hazard model; coefficients are reported as hazard ratios. I stratify by the offense in the Cox regression, which is the analogue of including fixed effects in a linear regression. Outliers are defined as observations for which time served is more than three standard deviations from the mean. 
Table 3. The effect of time served on recidivism, using the parole grid cut-offs

\begin{tabular}{|c|c|c|c|c|c|}
\hline & $\begin{array}{l}\text { Nä̈ve OLS } \\
\text { (1) }\end{array}$ & $\begin{array}{l}I V \\
(2) \\
\end{array}$ & $\begin{array}{l}I V \\
(3) \\
\end{array}$ & $\begin{array}{l}I V \\
\text { (4) } \\
\end{array}$ & $\begin{array}{l}I V \\
(5) \\
\end{array}$ \\
\hline $\begin{array}{l}\text { Time served, in } \\
\text { months }\end{array}$ & $\begin{array}{l}-0.00350 \\
(0.00032)\end{array}$ & $\begin{array}{c}-0.0134 \\
(0.00783)\end{array}$ & $\begin{array}{c}-0.0161 \\
(0.00768)\end{array}$ & $\begin{array}{c}-0.0387 \\
(0.00883)\end{array}$ & $\begin{array}{c}-0.0876 \\
(0.00348)\end{array}$ \\
\hline Black & $\begin{array}{c}0.027 \\
(0.0050\end{array}$ & $\begin{array}{c}0.023 \\
(0.0063)\end{array}$ & $\begin{array}{c}0.029 \\
(0.0052)\end{array}$ & $\begin{array}{c}0.026 \\
(0.016)\end{array}$ & $\begin{array}{c}0.093 \\
(0.0079\end{array}$ \\
\hline Male & $\begin{array}{c}0.031 \\
(0.0065)\end{array}$ & $\begin{array}{c}0.060 \\
(0.024)\end{array}$ & $\begin{array}{c}0.065 \\
(0.018)\end{array}$ & $\begin{array}{c}0.13 \\
(0.011)\end{array}$ & $\begin{array}{c}0.051 \\
(0.012)\end{array}$ \\
\hline Age at release & $\begin{array}{c}-0.0061 \\
(0.00077)\end{array}$ & $\begin{array}{c}-0.0054 \\
(0.00085)\end{array}$ & $\begin{array}{l}-0.0044 \\
(0.0008)\end{array}$ & $\begin{array}{l}-0.0046 \\
(0.0011)\end{array}$ & $\begin{array}{l}-0.0051 \\
(0.0011)\end{array}$ \\
\hline $\begin{array}{l}\text { Prior felony } \\
\text { incarcerations }\end{array}$ & $\begin{array}{c}0.032 \\
(0.0027)\end{array}$ & $\begin{array}{c}0.034 \\
(0.0033)\end{array}$ & $\begin{array}{c}0.036 \\
(0.0037)\end{array}$ & $\begin{array}{c}0.036 \\
(0.0057)\end{array}$ & $\begin{array}{c}0.044 \\
(0.0033)\end{array}$ \\
\hline Sentence fixed effects? & No. & Yes. & Yes. & Yes. & Yes. \\
\hline Offense fixed effects? & No. & No. & Yes. & Yes. & Yes. \\
\hline Sub-sample & $2-17 \mathrm{pts}$ & $2-17$ pts & 2-17 pts. & $7-10$ pts. & $2-17 \mathrm{pts}$ \\
\hline Instruments & N/A & $\begin{array}{l}\text { Dummies for } \\
\text { greater than } 8 \\
\text { and } 13 \text { points }\end{array}$ & $\begin{array}{l}\text { Dummies for } \\
\text { greater than } 8 \\
\text { and } 13 \text { points }\end{array}$ & $\begin{array}{l}\text { Dummy for } \\
\text { greater than } 8 \\
\text { points }\end{array}$ & $\begin{array}{l}\text { Suggested } \\
\text { sentence from } \\
\text { grid }\end{array}$ \\
\hline Observations & 28,096 & 28,096 & 28,096 & 8,062 & 17,579 \\
\hline R-squared & 0.1089 & 0.0472 & 0.0455 & 0.0718 & 0.1335 \\
\hline
\end{tabular}

Notes: The dependent variable is a dummy variable equal to one if the inmate returned to prison within three years of release and zero otherwise. All regressions are second-stage estimations using a linear probability model. Sentence fixed-effects are created by rounding an inmate's sentence to the nearest multiple of twelve months. Dummies for year of release as well as a quartic function of points are included in each regression except for that in Col. (4), in which only a linear control is used. (Recall that points are based on background characteristics and are calculated for each inmate upon admission, and then are later used in the grid to determine the recommendation for time served.) In Col. (5), point fixed effects are included. 
Table 4. Differential treatment effects of time served on recidivism

\begin{tabular}{|c|c|c|c|c|}
\hline Category & $\begin{array}{l}\text { Age } \\
\text { (1) }\end{array}$ & $\begin{array}{c}\text { Prior felony } \\
\text { incarcerations } \\
(2)\end{array}$ & $\begin{array}{c}\text { Drug offenses } \\
\text { (3) } \\
\end{array}$ & $\begin{array}{l}\text { Length of time } \\
\text { served } \\
(4)\end{array}$ \\
\hline & Age $\leq 25$ & None & Drug offenders & Time $\leq 20$ \\
\hline $\begin{array}{l}\text { Coefficient on } \\
\text { time served }\end{array}$ & $\begin{array}{l}-0.00936 \\
(0.00411)\end{array}$ & $\begin{array}{l}-0.00432 \\
(0.00478)\end{array}$ & $\begin{array}{r}-0.00172 \\
(0.0127)\end{array}$ & $\begin{array}{l}-0.0255 \\
(0.0080)\end{array}$ \\
\hline $\begin{array}{l}\text { Avg. recidivism } \\
\text { for the group }\end{array}$ & 0.28 & 0.21 & 0.23 & 0.29 \\
\hline \multirow[t]{2}{*}{ Observations } & 7671 & 6874 & 7508 & 9928 \\
\hline & Age $>25$ & At least one & Other offenders & Time $>20$ \\
\hline $\begin{array}{l}\text { Coefficient on } \\
\text { time served }\end{array}$ & $\begin{array}{c}-.00952 \\
(0.00432)\end{array}$ & $\begin{array}{l}-0.00981 \\
(0.00385)\end{array}$ & $\begin{array}{l}-0.00826 \\
(0.00303)\end{array}$ & $\begin{array}{l}-0.00780 \\
(0.00364)\end{array}$ \\
\hline $\begin{array}{l}\text { Avg. recidivism } \\
\text { for the group }\end{array}$ & 0.26 & 0.34 & 0.28 & 0.25 \\
\hline Observations & 20,425 & 21,222 & 20,588 & 18,168 \\
\hline
\end{tabular}

Notes: All coefficients are taken from regressions analogous to that in Table 3, Col. (5). See notes to Table 3 for more information on the specification. 
Table 5. The effect of limiting the parole board's discretion on inmate outcomes

\begin{tabular}{|c|c|c|c|c|c|c|}
\hline & $\begin{array}{c}\text { Infraction } \\
\text { rate } \\
\text { (1) }\end{array}$ & $\begin{array}{c}\text { Non- } \\
\text { violent } \\
\text { infr. rate } \\
\text { (2) }\end{array}$ & $\begin{array}{l}\text { Program } \\
\text { completion } \\
\text { rate } \\
\text { (3) }\end{array}$ & $\begin{array}{c}\text { Program } \\
\text { enrollment } \\
\text { rate } \\
(4)\end{array}$ & $\begin{array}{c}\text { Recidivism } \\
\text { rate - OLS } \\
\text { (5) }\end{array}$ & $\begin{array}{c}\text { Recid. rate } \\
\text { - hazard } \\
\text { (6) }\end{array}$ \\
\hline $90 \%$ dummy & $\begin{array}{c}0.0141 \\
(0.0022)\end{array}$ & $\begin{array}{c}0.0227 \\
(0.0110)\end{array}$ & $\begin{array}{l}-0.0007 \\
(0.0009)\end{array}$ & $\begin{array}{l}-0.0014 \\
(0.0009)\end{array}$ & $\begin{array}{l}-0.0333 \\
(0.0170)\end{array}$ & $\begin{array}{c}0.599 \\
(0.0871)\end{array}$ \\
\hline $90 \% \times$ After & $\begin{array}{c}0.00376 \\
(0.00039)\end{array}$ & $\begin{array}{l}0.00652 \\
(0.0014)\end{array}$ & $\begin{array}{c}-0.0085 \\
(0.00088)\end{array}$ & $\begin{array}{c}-0.0086 \\
(0.00088)\end{array}$ & $\begin{array}{c}0.0250 \\
(0.00923)\end{array}$ & $\begin{array}{c}1.847 \\
(0.254)\end{array}$ \\
\hline Male & $\begin{array}{c}-0.00500 \\
(0.0047)\end{array}$ & $\begin{array}{c}-0.0030 \\
(0.006)\end{array}$ & $\begin{array}{c}-0.0214 \\
(0.00823)\end{array}$ & $\begin{array}{l}-0.0201 \\
(0.0017)\end{array}$ & $\begin{array}{c}0.0908 \\
(0.0102)\end{array}$ & $\begin{array}{c}1.506 \\
(0.0228)\end{array}$ \\
\hline Black & $\begin{array}{c}0.0167 \\
(0.0017)\end{array}$ & $\begin{array}{c}0.0431 \\
(0.00384)\end{array}$ & $\begin{array}{c}-0.0048 \\
(0.00074)\end{array}$ & $\begin{array}{c}-0.0044 \\
(0.000762)\end{array}$ & $\begin{array}{c}0.0339 \\
(0.00993)\end{array}$ & $\begin{array}{c}1.143 \\
(0.0636)\end{array}$ \\
\hline $\begin{array}{l}\text { Prior } \\
\text { incarcerations }\end{array}$ & $\begin{array}{c}0.000509 \\
(0.0007)\end{array}$ & $\begin{array}{c}0.0540 \\
(0.0055)\end{array}$ & $\begin{array}{c}-0.0019 \\
(0.00071)\end{array}$ & $\begin{array}{c}-0.014 \\
(0.00124)\end{array}$ & $\begin{array}{c}0.0461 \\
(0.00222)\end{array}$ & $\begin{array}{c}1.216 \\
(0.0141)\end{array}$ \\
\hline Age at release & $\begin{array}{l}-0.00341 \\
(0.0003)\end{array}$ & $\begin{array}{c}-0.0064 \\
(0.00042)\end{array}$ & $\begin{array}{c}0.0002 \\
(0.00001)\end{array}$ & $\begin{array}{c}0.00017 \\
(0.00063)\end{array}$ & $\begin{array}{l}-0.00773 \\
(0.00123)\end{array}$ & $\begin{array}{c}0.961 \\
(0.0025)\end{array}$ \\
\hline Months served & $\begin{array}{l}0.00271 \\
(0.0002)\end{array}$ & $\begin{array}{c}0.0047 \\
(0.00067)\end{array}$ & $\begin{array}{c}-0.0006 \\
(0.00013)\end{array}$ & $\begin{array}{c}-0.0005 \\
(0.000108)\end{array}$ & $\begin{array}{l}-0.00773 \\
(0.00146)\end{array}$ & $\begin{array}{c}0.978 \\
(0.0066)\end{array}$ \\
\hline Observations & 22,124 & 22,124 & 18,642 & 18,642 & 18,832 & 21,042 \\
\hline R-squared & 0.1439 & 0.1226 & 0.1993 & 0.2111 & 0.1196 & -- \\
\hline
\end{tabular}

Notes: All regressions include year-of-offense, offense, and sentence fixed effects and are estimated using OLS; all standard errors are clustered at the level of " $90 \%$ x After." The sentence fixed effects absorb every twelve-month multiple of the original sentence variable. All inmates in these regressions have sentences between six and 60 months (though the results are robust to changing the upper bound to 120 months, as in Tables 1-4). The results are robust to adding a separate time trend for $90 \%$ offenses. As referenced in Appendix B, the coefficient (standard error) on the interaction term when one-year instead of three-year recidivism is used as the dependent variable in Col. (5) is $0.0148(0.00145)$. 